FALKENBURG
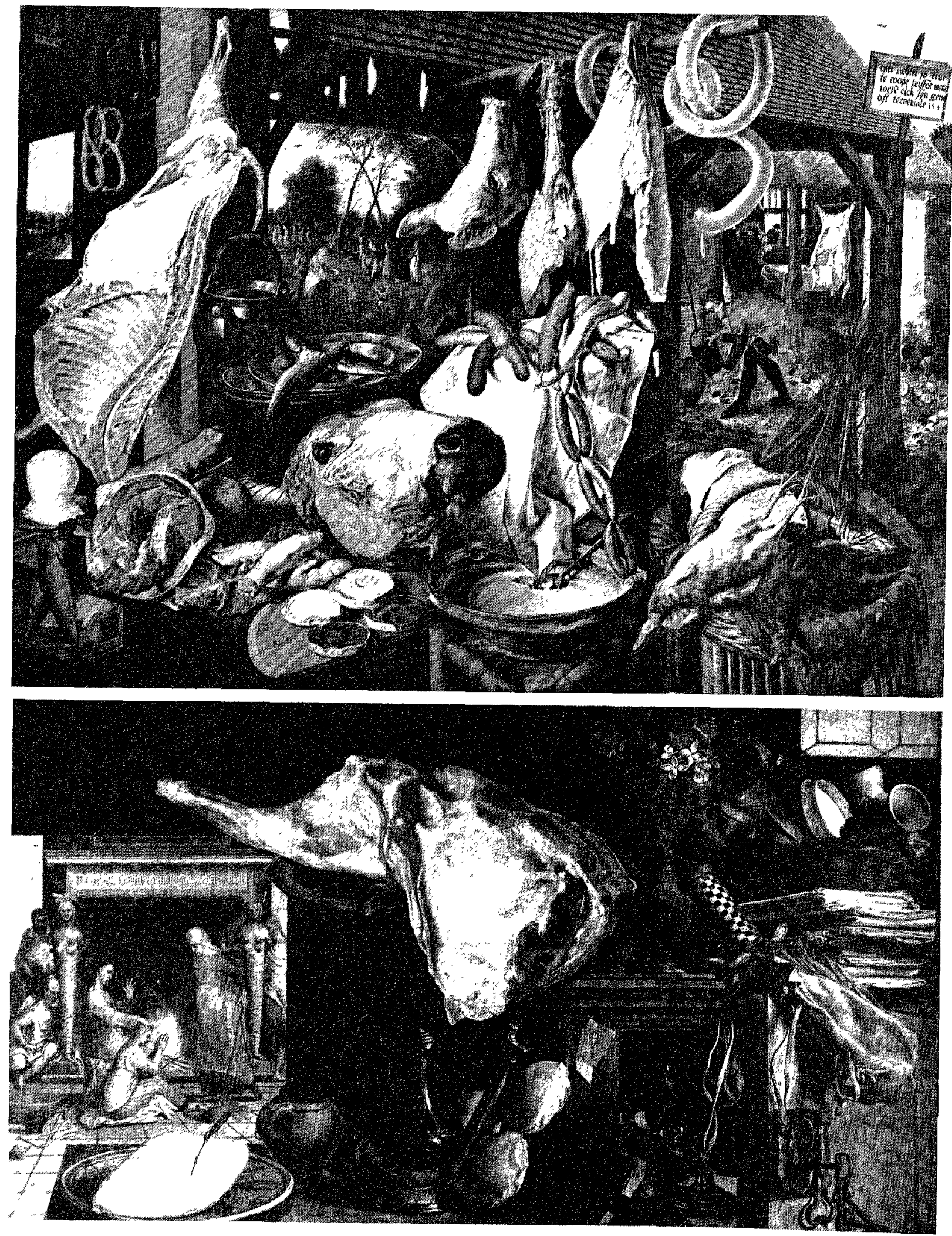


\title{
'Alter Einoutus': Over de aard en herkomst van Pieter Aertsens stilleven- conceptie
}

\author{
Reindert L. Falkenburg
}

In de kunsthistorische literatuur bestaat nog geen consensus omtrent de aard en de herkomst van de conceptie die ten grondslag ligt aan de stilleven-komposities in Pieter Aertsens marltuscènes en keuken-1nterieurs. De nadrukkelıjke presentatie in dere schilderijen van groenten, vleespartijen, vis, gevogelte, vruchten, noten, boter, melk, ereren en bakwaren is veelal herleid tot Aertsens fascinatie voor de zichtbare werkelyjkheid en tot 11 n behoefte of die van van zijn publiek - aan esthetisch genot van de in deze schilderijen vereeuwigde vergankelijke etenswaar. De esthetische appreciatie van de naturalistische weergave van deze etenswaar kan tot Aertsens etgen t1jd (Hadranus Juntus en Carel van Mander) worden getraceerd, en is dan ook steeds verdisconteerd in alle andere beweegredenen voor het concipieren van de stilleven komposities die men Aertsen heeft toegeschreven. ${ }^{1}$ De kleine bıjbel-scène op de achtcrgrond van verschillende schilderijen is daarbi1, vooral door stijlhistort$\mathrm{c}$, beschouwd als alleen een aanlerding tot het schilderen van het stilleven op de voorgrond ${ }^{2}$ Ikonografisch onderzoek van vooral de laatste jaren heeft aangetoond dat in vele individuele stilleven-motieven symbolische connotaties van sexuele aard schulen, en dat de relatie tussen het stilleven op de voorgrond en het bijbelverhaal op de achtergrond bepaald is door een inhoudelijke antithese: hie1 wereldse motieven die wijen op 1 mmoreel gedrag, daar een religieuze scène wijzend op morecl exempla1r gedrag ${ }^{3}$ Len verklaring voor de nadrukkelijke presentatie van deze wereldse motieven op de voorgrond is daarbij meestal gegeven in functionele termen. De groot in beeld gebrachte en met vcel acribre weergegeven etenswaren zouden de beschouwer aleit hebben gemaakt voor de dre1gende verleiding, zich visueel - maar wellicht ook anders/ns over te geven aat de 'voluptas carnıs' 4 Sterling heeft, Londer op Aertsens schilderijen in het detail in te gaan, gepoogd het ontstaan van het stilleven in de rorte ceuw in zijn algemeenheid te herleiden tot een reanimatie van een antick gense: de 'rhypatographe' de schildering van 'lage' en nederige onderwerpen. $H_{11}$ heeft de veronderstelling geut dat Aertsen en andere I 6de-eeuwse (Italiaanse) schilders op het 1dee $/ 1$ jn gebracht onbeduidende objecten tot een zelfstandig onderwerp van ect schilderiy te maken door het voorbeeld van de Griekse schilder Piralkos, die /lch volgens Plinius toelegde op het schildeten van 'happers- en schoenmakerswinkels, ezels, eetwaren en soortgelyke zaken'. 'Men weet niet of Aeitsen zichzelf met dere antieke schilder heeft vereenzelvigd, maa1 feit 15 dat reeds $\% 1 \mathrm{jn}$ t1jdgenoot Hadranus Junius ( 1588 ) beide schilders met ellaar in verband heeft gebracht ${ }^{6}$ Tenslotti / ijn, ook zeer recentelyk nog, psychologiseren- 


\title{
'Alter Einoutus': Over de aard en herkomst van Pieter Aertsens stilleven- conceptie
}

\author{
Reindert L. Falkenburg
}

In de kunsthistorische literatuur bestaat nog geen consensus omtrent de aard en de herkomst van de concepte die ten grondslag ligt aan de stilleven komposities in Pieter $\Lambda$ ertsens markt scenes en keuken-1nte ricurs De nadiukkelijke presentatie in deze schilderijen van groenten, vleespartijen, v1s, gevogelte, viuchten, noten, boter, melk, e1eren en bak waren is veelal herle1d tot $\Lambda$ eitsens fascinatie voor de zichtbare werkelijk herd en tot /1jn behoefte - of die van van /1jn publiek - aan esthetisch genot van de in deze schilderijen vereeuwigde veigankelijke etenswaar De esthetische appreciatie van de naturalistische weesgave van deze etenswaar kan tot Aertsens ergen tijd (Hadruanus Junius en Carel van Mande1) worden getiaceerd, en 1s dan ook steeds verdisconteerd in alle andere beweegredenen voot het concipieren van de stilleven komposities die men Aertsen heeft toegeschreven ${ }^{1}$ De hlene bijbel-scene op de ach tergrond van veischillende schildetyen is daatbiy, vooral door stijhistort$\mathrm{c}$, beschouwd als alleen ecn aanleiding tot het schilderen van het stilleven op de voorgrond ${ }^{2}$ Ikonografisch onder heeft aangetoond dat in vele individuele stilleven motieven symbolische connotaties van sexuele aaid schuilen, en dat de relatie tussen het stilleven op de voorgrond en het bijbelverhaal op de achtergrond bepaald is door een inhoudelijke antithese hier wereldse motieven die wijzen op immo recl gedrag, daar een 1 eligieure scene wiyend op morcel exemplair ge drag ${ }^{3}$ Een verklarıng voor de nadrukkelıke presentatie van deze wereld se motieven op de voorgiond is daarbij meestal gegeven in functionele

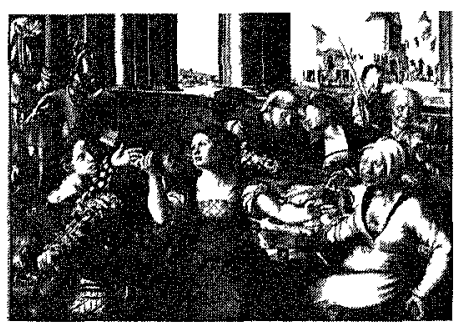

I Puler Aorten, De Vleessial, Uppsala, Collectze van de Unuversalcal

2 Pleter Acusen, Cbrestur in bet bues van Maria en Martha, W'encn, Kumwhestortsches Muscum

3 Jan van Llemessen, Bordaliane mat dc Verloren /oon, Brursel, Kontnklyhoc Musca voor Scbone Kumsin termen De groot in beeld gebrachte en met veel acribie weergegeven etenswaen souden de beschouwer alert hebben gemaakt voor de die1 gende verleiding, zich visueel maar wellicht ook anderszins over te geven aa* de 'voluptas carnis' 4 Sterling heeft, rondet op Nertsens schil derijen in het detall in te gaan, gepoogd het ontstaan van het stilleven in de ibrte eeuw in zijn algemeenhe1d te herletden tot een reanımatie van een antick genre de 'rhyparographie' de schildering van 'lage' en nederige onderwerpen $H_{1 j}$ heeft de veronderstelling geuit dat Acitsen en andere I odc eeuwse (Italiaanse) schilders op het idee 71 1n gebracht onbedurdende objcten tot een zelfstandig onderwerp van een schilderil te maken door het voorbeeld van de Griekse schilder Piratkos, die /1ch volgens Plinius toelegde op het schildeien van "kappers en 'choenmake1swinhels, ezels, eetwaren en soortgelijke /aken' 5 Men weet niet of $\Lambda$ ertsen /1ch des antieke schilder heett vereenzelvigd, maar fett is dat reeds $210 \mathrm{n}$ tijd genoot I ladianus Junius (1588) berde schildes met ellaar in verband heeft gebracht ${ }^{6}$ Tenslotte $/ 1 \mathrm{jn}$, ook reet 1ecentelık nog, psychologiseren 
de vcrklaringen geopperd voor het plotselinge verschinnen in de Neder landse 16 de eeuwse schilderkunst van Aertsens indringende schildering van aards voedsel Deze verklaringen varieren van de wilde suggestie dat Aertsen of 11 n opdrachtgevers leden aan een psychisch complex, veroorsaakt door voedselschaarste, hetgeen hun verlangen zou hebben doen ontbranden naar een 'visuele compensatie', tot de bedachtcamer these dat Aertsens concentratie op wereldlijke taferelen - boeren zowel als stilleven-motieven een reactie kan /1jn geweest op de beeldenstorm waaraan zovele van $71 j \mathrm{jn}$ religieuze altaarstukken ten offer zijn gevallen ${ }^{7}$

Terw1jl Sterlings these een aantal auteurs aantrekkelijk voorkomt, neemt /1] $_{1}$ in de kunsthistorische discussie over Aertsen slechts een bescheiden plaats in, hetgeen niet verwonderlyjk is daar deze these bif het ontbreken van vrijwel elke schriftelijke bron omtrent de denkwereld en de culturele achtergrond van Aertsen en /1,n koperspubliek, voor deze schilder nog moellijk bewijsbaar $1 \mathrm{~s}^{8}$ Meer in het centrum van het debat staat de kwestie of Aertsens stillevens nu primair in malo moeten worden u1tgelegd, dat wil reggen als voorstellingen waarvan de esthet1sche aan trekkingskracht vooral is aangewend om de toeschouwer te beleren om trent de zondigheid van rinnelijke gentetingen, dan wel in bono - als voorstellingen die primair bedoeld $z 1$ in als positief appel op het esthetisch zingenot van de beschouwer In de jongste literatuur tendeert men naar een multi interpretabiliteit van de voorstelling, en veronderstelt men overigens zonder deze 1dee met enige r6de eeuwse bron kracht bil te ctten dat de toenmalige beschouwer (en men bedoelt conform de bedoelingen van de schilder) Aertsens schilderijen rowel op de gene wije kon uttleggen en waarderen ${ }^{9}$ Achtergrond voor deze ver klarıngswije is klaarblijkelijk een gcvoclen dat de negatieve symboliek die ikonografen hebben blootgelegd alsmede de discursieve wijze van interpreteren die dit met zich meebrengt, niet, althans niet tegelijkertijd, te rijmen valt met een 'empathisch' esthetisch genot waaraan $\Lambda$ ertsens stilleven motieven appelleren, noch met de hefdevolle aandacht voor deze motieven die lijkt te spreken uit de naturalıstısche wije waarop deze motieven $21 \mathrm{j}_{\mathrm{n}}$ weergegeven en uit de prominente plaats die daarvoor in de kompositie is ingeruimd 10 Men bespeurt naar het schijnt een discrepantie tussen 'negatieve' symboliek en 'positieve' vormgeving, die de moderne interpreet ervaart als een innerlijke tegenspraak, en die hem ertoe brengt de in malo uitleg en de in bono-uitleg in verschillende, van clkaar te scherden receptie-wiyen onder te brengen

Het komt mij voor dat de discrepantie tussen 'negatieve' inhoud en 'positieve' vorm inderdaad de kern betreft van waar het in Pleter Aertsens schilderijen om gaat, maar dat dc se discrepantie als een samenhan gend verschijnsel verklaard moet worden dat een coherente wijze van recipseren impliceert In het onderstaande $/$ al $1 \mathrm{k}$ trachten aan te tonen dat vorm en inhoud in Pieter Aertsens stillevens in een bepaald op/icht inder-

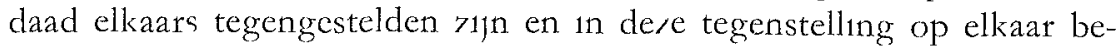
trokken $/ 1 \mathrm{j}$, en dat de $z$ e antithctische relatie tussen vorm en inhoud een specifieke stiflfigurur thhoudt, die de grond conceptie vormt voor $/ 1$, 


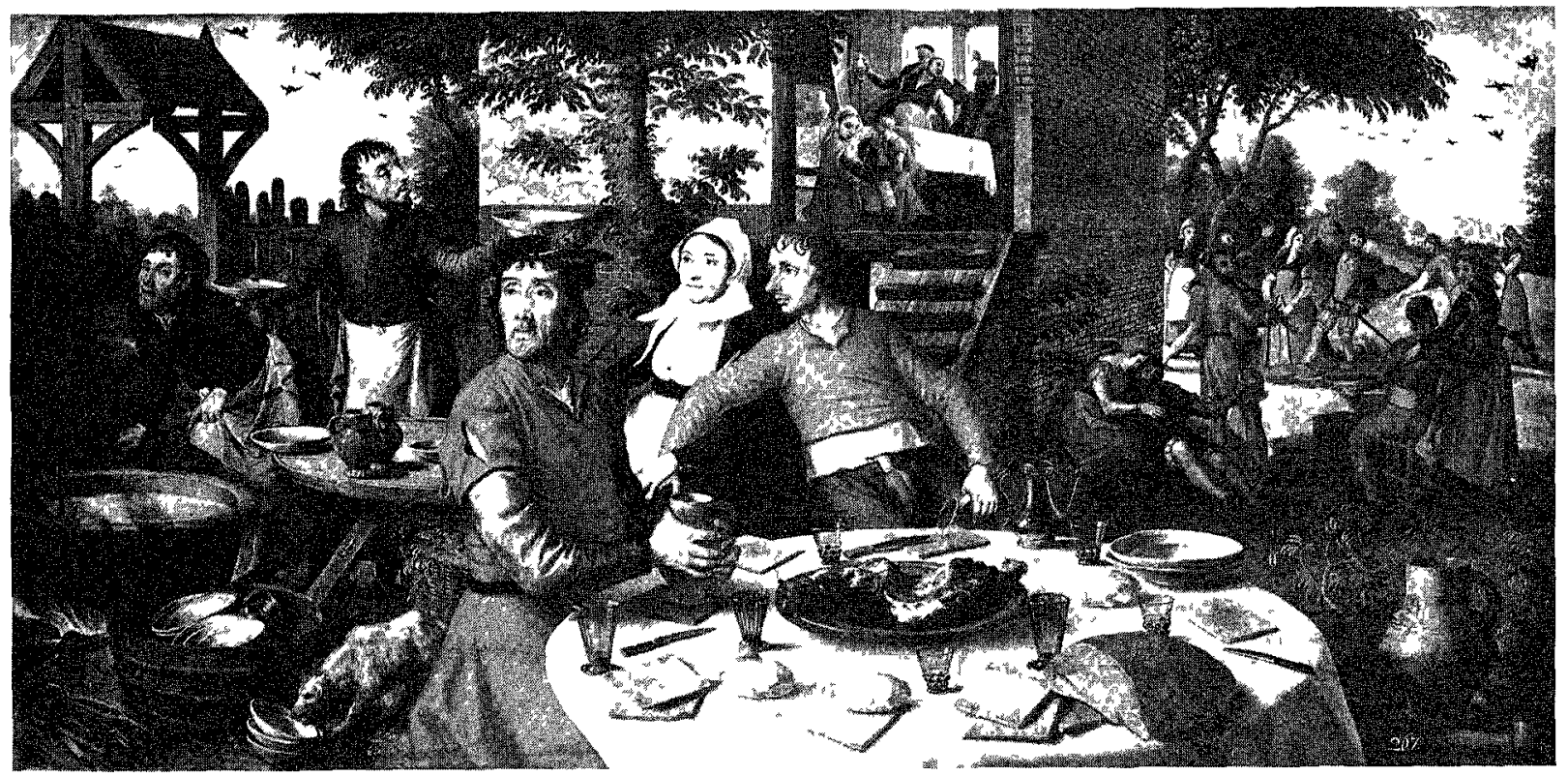

4 Pieter Aertsen, Boerenfeest, Wenen, Kunsthtsiortsches Museum. stilleven-voorstellingen. Om een basis voor een interpretatie in deze zin te verkrijgen wend ik mij eerst tot de herkomst van het kompositie-type van zijn stilleven-voorstellingen, en vervolgens tot een aantal van zijn schilderijen waarin boerse personages de hoofdrol spelen.

Verschillende auteurs hebben erop gewezen dat het kompositie-type van Aertsens stilleven-schilderijen, alsook van een aantal bocren-voorstellingen, herleid kan worden tot werken van de $\Lambda$ ntwerpse schilders Marinus van Reymerswael en Jan van Hemessen daterend uit de eerste helft van de I6de eeuw. ${ }^{11}$ Met name Hemessens Bordeelscene met de Verloren Zoon uit 1536, in Brussel (afb. 3), ${ }^{12}$ wordt vaak aangehaald als een direkt voorbeeld voor Aertsens kompositie-schema, volgens welk het profane motief op de voorgtond groot in beeld is gebracht en een religieuze vertelling, uitgebeeld met één of meer kleine scènes, ver op de achtergrond is geplaatst (aflo. I en 2). ${ }^{13}$ Raupp heeft dit kompositie-type ook onderkend in boeren-voorstellingen met een kleine profane scène op de achtergrond (afb. 4) ${ }^{14}$ In één opzicht echter verschillen Aertsens voorstellingen van die van zijn voorgangers: zij bezitten niet alleen in de weergave van de etenswaar en de bijbehorende markt- en keuken-utensiliën, maar ook in de schildering van boeren en keukenmeiden op de voorgrond een statische, 'stilleven-achtige' kwaliteit, terwijl de voorgrond-figuren bij Reymerswael en Hemessen in een vaak drukke handeling verwikkeld zijn. Recds Riegl onderkende deze kwaliteit in $\Lambda$ ertsens voorstellingen van bocren c.s., die voortvloeit uit het feit dat de figuren in hun handeling ten opzichte van clkaar geìsoleerd zijn, en iedere figuur afzonderlijk op de beschouwer gefixeerd is volgens Raupp een profane 'Modus der Buldsprache' die kenmerkend is voor de onderhavige groep schilderijen, en die niet in zijn zuiver religieuze werken an te treffen is. ${ }^{15}$ 


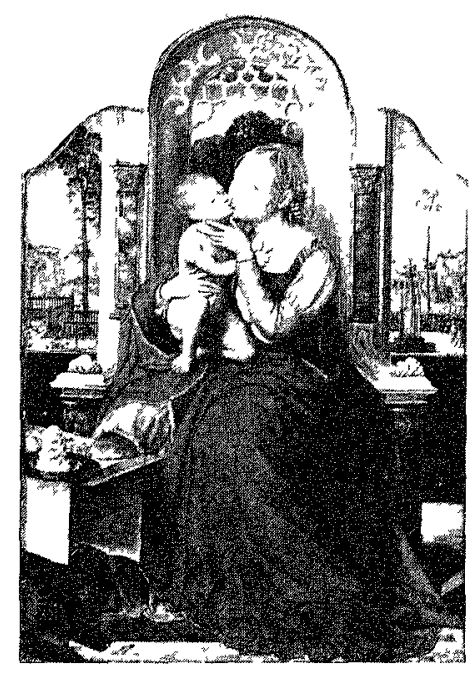

TALKJ NBURG

Het komt mij echter voor dat deze 'modus' juist herleid moet worden tot het kompositie-schema van een grote groep religieuze schilderijen, die in de discussie over de herkomst van Aertsens stilleven-conceptie tot nog toe buiten beschouwing is gebleven. Deze schilderijen vertonen ntet alleen een vergelijkbare 'statische modus' in de presentatıe van voorwerpen en figuren op de voorgrond, maar ook een kompositie-schema dat identick is aan de opbouw van Aertsens stilleven-en boeren-voorstellingen. Ik doel op een type devotie-schilderij of ' $\Lambda$ ndachtsbild' - dat in het werk van vele van zijn tijdgenoten aan te treffer 1 , en waarin Maria met het kind, of een heilige, op de voorgrond is afgebeeld te midden van bloemen, planten en andere stlleven-motieven in een van de achtergrond afgescheiden ruimte, terwijl een doorkijk achter de protagonist uitzicht

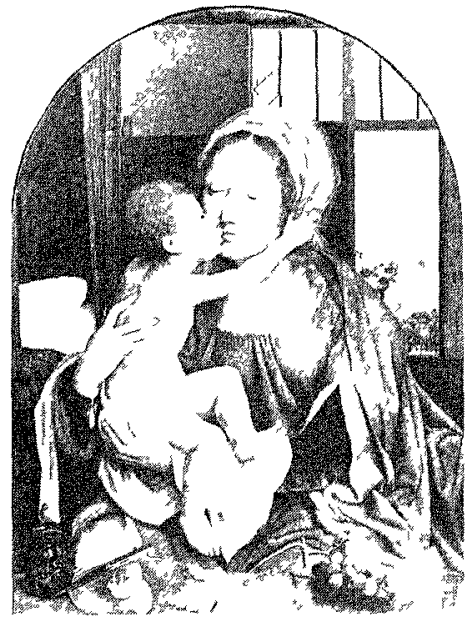
biedt op een landschapsdecor. Hier zijn in feite twce varianten te onderscheiden. In schilderijen van de eerste variant zijn de heilige personen ten voeten uit weergegeven, terwijl een open zuilen-arcade, een baldakijn of boomgroep het landschap achter hen in verschillende compartimenten verdeelt. In de andere variant zijn de personen op de voorgrond nog dichter bij de beschouwer geplaatst, zijn zij in half-figuur uitgebeeld, en geeft een vensteropenng in een verder gesloten interieur aan één zijde van de kompositie uitzicht op een landschap. Beide varianten van dit type 'Andachtsbild' zijn aan te treffen in het werk van prominente IGde-eeuwse Antwerpse kunstenaars als Quinten Massys, Barend van Orley en Joos van Cleve (afb. 5-10), ${ }^{16}$ alsook in schilderijen van P1eter Coecke van Aclst en Jan van Hemessen (afb. I I-14), ${ }^{17}$ van wier werk verschillende auteurs ook in andere opzichten een stilistische verwantschap met Pieter $\Lambda$ ertsens schilderijen hebben aangetoond. In menig schilderij van dit type kan men in het achtergrond-landschap één of meer kleıne scènes bespeuren die het

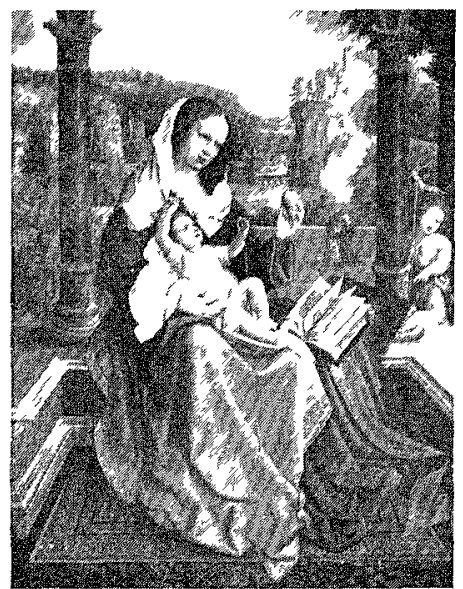

s Omnten Massy, Marza met kent, Berlyn-West, Gemaldequlerie Sacaliche Museen Proussichor Kulurberto.

6 Qunten Massys, Maria mot kend en druwentros, Parys, Malée du Lowne.

7 Barend van Orley, Marza mel kend en Jobannes de Doper, Mastrul, Museo del Pradts. devotic-motief op de voorgrond in de context van een bepaalde religieuze vertelling plaatsen, zoals in Joos van Cleves Kersenmadonna in Aken (afb. Io), waar scènes van de legende van de vlucht taar Ligypte de voorstelling van Maria met het kind op de voorgrond doen begrijpen als de 'rust op de vlucht'. ${ }^{18}$

Dit type kompositie lijkt nu in beide varanten ook ten grondslag te liggen aan een reeks schilderijen van Pieter $\Lambda$ ertsen. De variant waarbij de voorgrond-motieven sterk in close-up zijn wecrgegeven en zijn gesitueerd in een interteur dat via cen vensteropening aan ćén zijde uitzicht biedt op een kleine scène met een religieure vertelling op de achtergrond, lijkt direkt te aljn overgenomen in Aertsens voorstellingen van Christus in het hus van Maria en Martha in Wenen en Rotterdam (afb. 2 en 15 ). ${ }^{19}$ ' T'evens lijkt dit type de grondstruktuur te bepalen van de kompositte in Nertsens Markescène met Cloristus en de overspelige vroun, in Stockholm (afb. 16), waar de scherding tussen voor-en achicrgrond opvallend gemarkeerd is. ${ }^{20}$

De tweede variant, met verschillende doorkijken naar een landschap op de achtergrond waarvan de kompartimenten samen de hele breedte van het beeldvlak beslaan, ligt mijns inziens ten grondslag aan de leesstal in Uppsala (afb. I), waar de houten palen van de marktstal dezelfde 

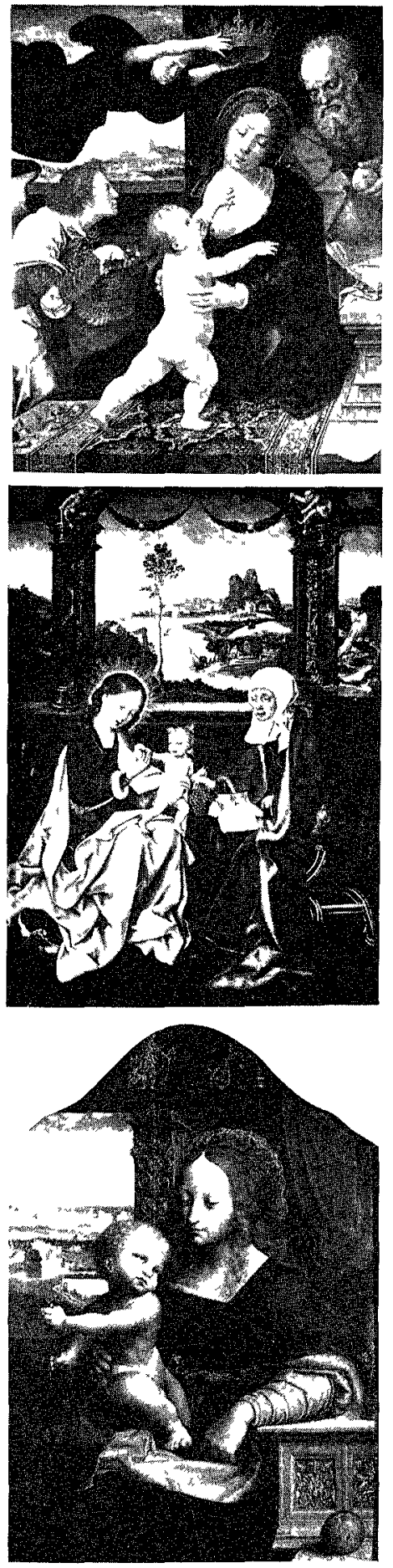

8 Barend van Orley, lloulige I'amhle met engelen, Madrid, Mrreo del Prado.

9 Joos van Clewe, Maria mel kand en de healige Anna, Modena, Gulleria Istense.

10 Joos van Cleve, Marka met keind met kersen, Aken, Suermondl-Ludnig Museum.

\section{'Alter Einoutus': Aertsens stillevenconceptie}

rol vervullen als de zuilen-arcaden in traditionele 'Andachtsbilder'. ${ }^{21}$ De komposities in Aertsens Marktscène met Clbristus en de overspelige vroum in Frankfurt (afb. 17), en de op zijn inventie teruggaande Groentestal met de wlucht naar Egypte in een particuliere collectie in Genua (afb. 18), ${ }^{22}$ beschouw ik als derivaten van dit schema. Hier zijn op de voorgrond boeren en hun marktwaar weergegeven in een statische close-up, en biedt het in verschillende compartimenten onderverdeelde landschap op de achtergrond plaatst aan een kleine religieuze scène; maar voor-en achtergrond worden niet door een architecturale vorm streng van elkaar gescheiden. Ook in Aertsens geheel profane voorstellingen zoals het Boeren-feest in Wenen (afb. 4) - met stilleven-motieven en statisch-geïsoleerde figuren op de voorgrond, één of meerdere doorkijken en een (wat Raupp noemt) 'explicatieve' scène op de achtergrond -, is het kompositie-schema geënt op het geschetste type ' $\Lambda$ ndachtsbild', vooral op de variant met de verschillende doorkijken (vergelijk afb. $19-22$ ). ${ }^{23}$

Men kan dus concluderen dat de structuur van de kompositie in zijn geheel alsmede de stilleven-kwaliteit van de op de voorgrond geposteerde figuren en uitgestalde etenswaar erop duidt, dat wij in Aertsens schilderijen met een 'Modus der Bildsprache' te maken hebben die traditioneel is voorbchouden aan de presentatie van de centrale personen in de heilsgeschiedenis en hun ambiance, maar hier is benut voor de etalering van boeren, marktlui en keukenpersoneel en allerhande op tafels, britsen en kruiwagens opgetaste etenswaar. Anders gezegd: Aertsen lijkt de 'hoge' modus van het traditionele 'Andachtsbild' te hebben gebruikt voor stilleven-komposities, waarvan de profane onderdelen - zeker wanneer men de sexuele connotaties verdisconteert die men daarvan heeft blootgelegd - moeten worden aangemerkt als bij uitstek 'lage' motieven. De vraag is nu, of de discrepantie tussen 'hoge' vorm en 'lage' inhoud die ik hier meen te konstateren, een a-historische voorstelling van zaken is, dan wel als zodanig door $\Lambda$ ertsen welbewust is nagestreefd en een specifieke bedoeling inhoudt. Om de kwalificatie 'hoog' versus 'laag' die hier an de orde is nader te beoordelen op haar waarde voor Acrtsens stilleven-komposities, wend ik mij eerst tot enkele van zijn schilderijen waar boeren en keukenmoiden de hoofdrol spelen.

Verschillende auteurs hebben erop gewezen dat $\Lambda$ ertsen boeren en keukenmeiden vaak voorstelt op een manier die niet past bij het onderwerp, dat wil reggen hun een voorname houding geeft in weerwil van hun boerse fysionome, kleding, handelingen en karakter. ${ }^{24}$ Van de Ketkenmeid in Brussel bijvoorbeeld (afb. 23) is gezegd dat Aertsen haar een 'monumentale' gestalte heeft gegeven, een 'grote vorm', dat zij een 'volkse vrouw' in 'ideale gestalte' 1s, een 'heroïsche', 'aristocratische' verschijning, met een 'kalme waardigheid', ja zelfs dat zij een 'Roman deity' 1s, 'a goddess of abundance or domesticity'. ${ }^{25}$ Dergelijke kwalificaties vloeien voort uit de observatie dat de vormentaal waarin deze keukenmeid is voorgesteld, net als de uitbeelding van boeren en marktlui in verscheidene andere schilderijen geïnspireerd lijkt op de grote voorbeel- 

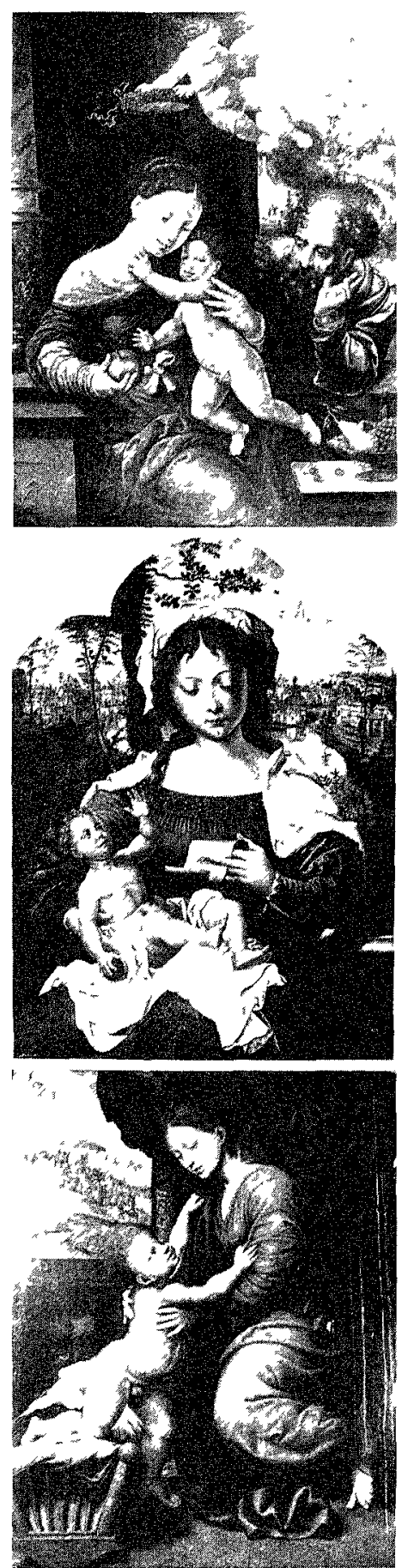

II Pueter Coecke van Aelst, Healige 1 amzle, Brugge, parlaculiere verzamelmg.

12 Peler Coocke van Aelsi, Maria met kind, Junk, Musée Curtus. 13 Jan van T temessen, Maria met kind, Brugge, croenngemusenm. den van de Italiaanse renaissance. De 'klassieke geest' van de Kenkenmeid en andere werken ziet men enerzijds tot uitdrukking komen in Aertsens ontleningen aan de houtsneden in Pieter Coecke van Aalsts editie van Serlio's verhandeling over de klassieke ordes, bij de uitbeelding van dorische, ionische, corinthische en composiete zuilen, loggia's en schouwen, die in verschillende voorstellingen de coulissen vormen voor de boeren en keukenmeiden en de etenswaar die zij onder hun hoede hebben. ${ }^{26}$ Anderzijds riet men reminuscentres aan een klassieke vormentaal in de houdingen van verschillende figuren, welke men herleidt tot antieke voorbeelden en de kunst van Raphael en Michelangelo. Zo acht Buchan het mogelijk dat de Keukenmeid teruggaat op (Italiaanse) prenten naar antieke allegorische voorstellingen met vrouwelijke personificaties van de overvloed en van seizoenen. ${ }^{27}$ Genaille ziet in de boer links op de voorgrond van de Eierdans (afb. 19) een direkte ontlening aan een hoekfiguur in de Sixtijnse kapel; de groep omstanders van. Christus en de overspelige vrouw op de achtergrond van het schilderij te Frankfurt (afb. 17) beschouwt hij als ontleend aan Raphaels School van Atbene in het Vatıcaan, terwijl de boeren op de voorgrond van het schilderij in Frankfurt volgens hem te herleiden zijn tot Michelangelo's Ignudi.28 Sievers traceert de bron voor Aertsens Boer in een nis in Boedapest (afb. 24) tot de waterdraagster in de Stanza met de Borgo-brand; het voorbeeld voor de omlijsting van de staande figuur van de boer met een stenen boog ziet hij, evenals Buchan, in contemporaine Italiaanse prenten waar allegorische figuren zijn voorgesteld als sculpturen staande voor een nis. ${ }^{29}$ Sievers, Genaille, Buchan e.a. menen ook in allerlei andere schilderijen van Aertsen direkte of indirekte formele ontleningen aan schilderijen van r6deeeuwse Italiaanse meesters te kunnen traceren - naast de genoemde schilders ook van Titaan, Tintoretto, Jotto en Jacopo Bassano. Ik acht het waarschijnlijk dat Aertsen voor de hier gesignaleerde, op Italiaans-klassieke voorbeelden geënte poses van boeren en keukenmeiden tekeningen en prenten heeft geraadpleegd die ook in andere Antwerpse ateliers moeten hebben gecirculeerd, zoals overeenkomsten met (prenten naar) schilderijen van Frans Floris duidelijk maken. Zo vindt het op een rieten mand balancerende been van de jonge boer op de voorgrond van de Isierdans zijn evenknie in het op een anticke zuil rustende been van koning Salomo in Ph. Galle's prent naar een vroeg schilderij van Floris; ook doen de elegante houding en het langgerekte lichaam van de jonge boer in hun algemeenherd sterk denken aan Floris' Michclangelesque vrouwelijke personificaties van de elementen, zoals die in prent zijn gebracht door F. Menton. ${ }^{30}$ De op Michelangelo teruggaande gedraaide houding van veel allegorische figuren van Floris, waarbij de benen in profiel, maar het bovenlichaam frontaal is weergegeven, is een motief dat tevens ten grondslag ligt aan de torsie in het lichaam van de boer in Aertsens schilderij te Boedapest. ${ }^{31}$ De frappante gelijkenis tussen de houding van de vogelverkoper in Aertsens Marketscine met Cbristus en de overspelige vroum, in Stockholm (afb. 16) en een der Ignudi rondom het tafereel van de dronkenschap van Noach in de Sixtijnse Kapel, geldt evenzeer de houding van 


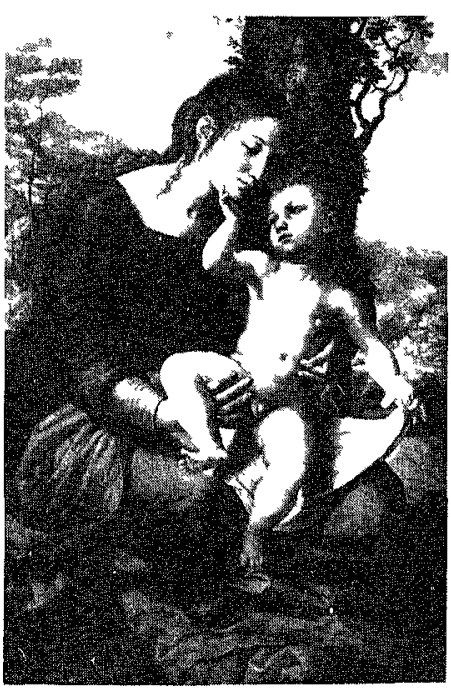

14 Jan wan Hemessen, Marza mot kend, Madrul, Museo dol Prado

1) Puler Airtscn, Cbrislus on bet but van Marta on Martha, Rollurdam, Murum Boymans van Buningen

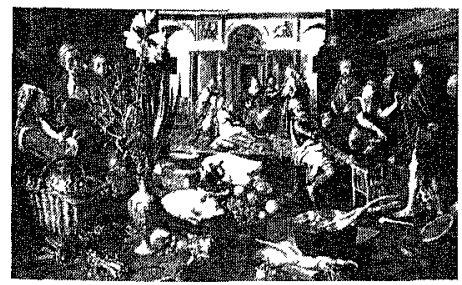

Venus in Flor's' Venus in de smudse van Vulcanus te Berlijn. ${ }^{32}$ Het heeft er de schijn van dat Aertsen hier zowel als in de andere gesignaleerde gevallen voor zijn weergave van boeren, marktlu1 en keukenpersoneel een Italaans vormen-repertolre heeft benut dat, los van de originele context der af7onderlijk motieven, als een soort staal van klassiek-Italiaanse vormen in Antwerpse ateliers circuleerde en voor uiteenlopende doeleinden kon worden aangewend. De vraag is nu of er bij deze 'klassieke' inkleding van boerse motieven sprake is van een beoogde kontrastwerking tussen vorm en tnhoud die een bepaalde functie heeft, dan wel van een inhaken zonder diepere zin - op de mode van wat 15 genoemd de 'romanistische' stijl van het midden van de i6de eeuw.

In een recente studie is Raupp uitvoerig ingegaan op de relatie tussen vorm en inhoud in r6de-eeuwse boeren-voorstellingen in de Duitse en Nederlandse kunst. ${ }^{33}$ De gehele bestaansgrond van deze voorstellingen ligt volgens Raupp in de verbeelding van een 'genus satıricum', een nederige kunstsoort waarın de karıkaturale weergave in een 'niedere Stıl' van oncedig, onbeheerst, zondig en asociaal gedrag van boeren (ook 'Marktbauern'), bedelaars en andere 'narren' qualutate qua besloten ligt. De vraag of deze weergave een 'realistische' weerspiegeling is van het gedrag van deze groepen, dan wel een rhetorische overdryving ten behoeve van de belering en het vermaak van een burgerluk publiek, is volgens Raupp secundair. Primair zijn voorstellıngen behorende tot dit genre geconcipieerd - en gerecipieerd - als zelfstandige 'Kunstubungen' gew1jd aan de nederige stijl als zodanig, waarin alle nadruk ligt op de virtuositeit van de kunstenaar in het hanteren van deze nederige stijl. 'Stujl' en 'genre' zijn hier verwisselbare begrippen; stijl betekent hier meer dan vormentaal of wijze van weergeven, en omvat naast wat st1jlhistoric1 hie1 gewoonlijk onder verstaan ook de boerse motieven zelf, alsmede de verschillende symbolische connotaties daarvan: dit te zamen vormt het in beeldtradities aangere1kte en grestandaardiseerde materıal voor een stıjlbegrip 'satire' dat bewust is g,ehanteerd en dat ontleend is aan de rhetorische 'genera dicendi' Vandenbrouck heeft er zijn tw1jfel over uitgesproken dat een dergelijk stı1-begrip en een hierarchie van genera die dit begrip impliceert, in de kunsttheor1e - laat staan in de kunstprakt1jk - gedurende de periode $147^{0}$ - 570 welke Raupps onde1\%oekingen beslaan, hebben bestaan $34 \mathrm{~V}$ andenbroeck heeft gelijk dat (zoals Raupp trouwens zelf al heeft aangegeven) in de kunsttheorie van de tyd een zelfstandig 'genus satır1cum' nog niet expliciet voorkomt. Dit sluit echter niet uit dat bij kunstenaars in de prakt1jk, vooral sinds Durer, wel degelijk een - 71 het begripsmatig wellicht minder vast omlijnd - besef van een 'laag genre' heeft bestaan. ${ }^{35}$ Zich baserend op het herboven omschreven 'niedere Strl'-begrip levert Raupp interpretaties van hele reeksen boeren-voorstellingen die de gedachte rechtvaardigen dat kunstenaars een decorum voor de voorstelling van boeren hebben aangehouden. De daarbij telkens terugherende formele kenmerken zijn: een plomp-gedrongen, naar het misvormde neigende lichaamsbouw, grove gezichtstrekken, een geexalteerde mimiek, hoekige, wilde lichaamsbewegingen en lompige kleding, met als 
16 Peter Aerisen, C.Jrisius en de overpelige vrom, stockbolm, Natzonalmusenm.

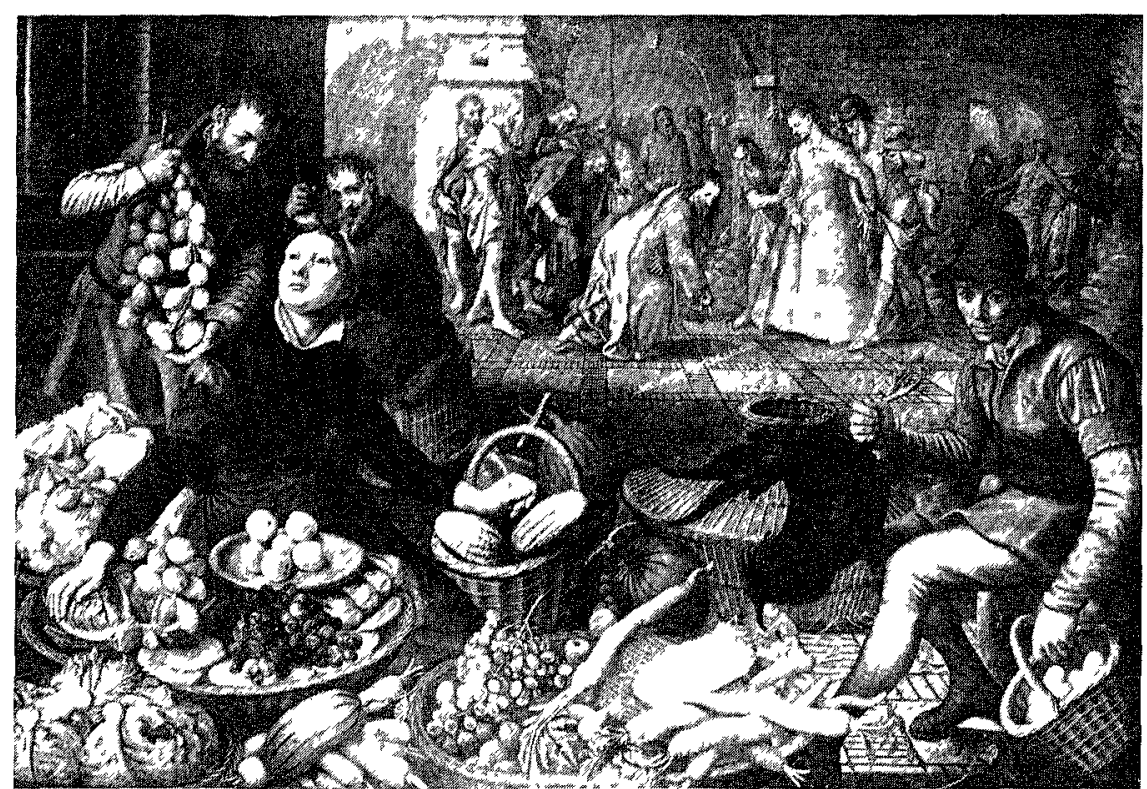

stilist1sche karakteristiek (bedoeld in de moderne 'z1n van het woord) een realistische, zeer gedetallecrde behandeling van de textuur van gezichten, kleding en allerhande onbeduidend bijwerk.

Naar Raupps eigen zeggen ontbreekt bij Pieter Aertsen juist deze gangbare karkaturale behandeling van het boeren-motief. ${ }^{36}$ Toch vindt men in verschillende schilderijen van zijn hand duidelijke sporen van dit decorum, zoals het vooral in contemporaine grafische voorstellingen van boeren is gevolgd. Door dronkenschap rood aangelopen gezichten, verwezen blikken, ongegeneerd tasten naar elkaars genitaliën en plompverkrampte houdingen treft men in dezelfde schilderijen, ja soms in zelfde figuren aan die reminiscenties aan de klassieke vormentaal bevatten (zle afb. 4, I6, 17 en 24). In het schilderij te Boedapest bijvoorbeeld is de houding van de boer alsmede de plaatsing van de figuur voor een rusticke arcade in zijn algemeenheid weliswaar gebaseerd op een klasslek-Italiaanse vormencanon; maar de fysionomie van de boer en de disproporties van zijn lichaam zijn tegelijkertijd geënt op de karikaturale weergave van boers uiterlijk in contemporaine grafiek. Men lette vooral op de anatomische anomalie van de ten opzichte van het bovenbeen verdraande linkerkuit en -voet, maar ook op de vreemde verhoudingen in grootte tussen tors en extremiteiten, alsmede op de ambivalentie in de stand (of 1 s het een loop-beweging?) van de figuur, dic een ontkenning lijkt in te houden van de zwaarte van de melkton op zijn hoofd. Het is precies dit ten dele volgen van het gangbare decorum en het ten dele volgen van cen klassiek-Italiaans idroom, dat Raupp karakteristiek acht voor Bruegels late monumentale voorstcllingen van boeren-feesten en -kermissen. ${ }^{37}$ Raupp zegt dat Bruegel als enige in zijn tijd een dergelijke kombinatie in het 'lage genre' heeft beproefd, en hij geeft als verklaring dat Bruegel hiermee dit genre heeft willen opwaarderen tot de rang van de historie- 
17 Pleter Aer/sen, Christus en de onerspelge vroum, Frankfurt a.M., Staedelsches Kunstinstilut.

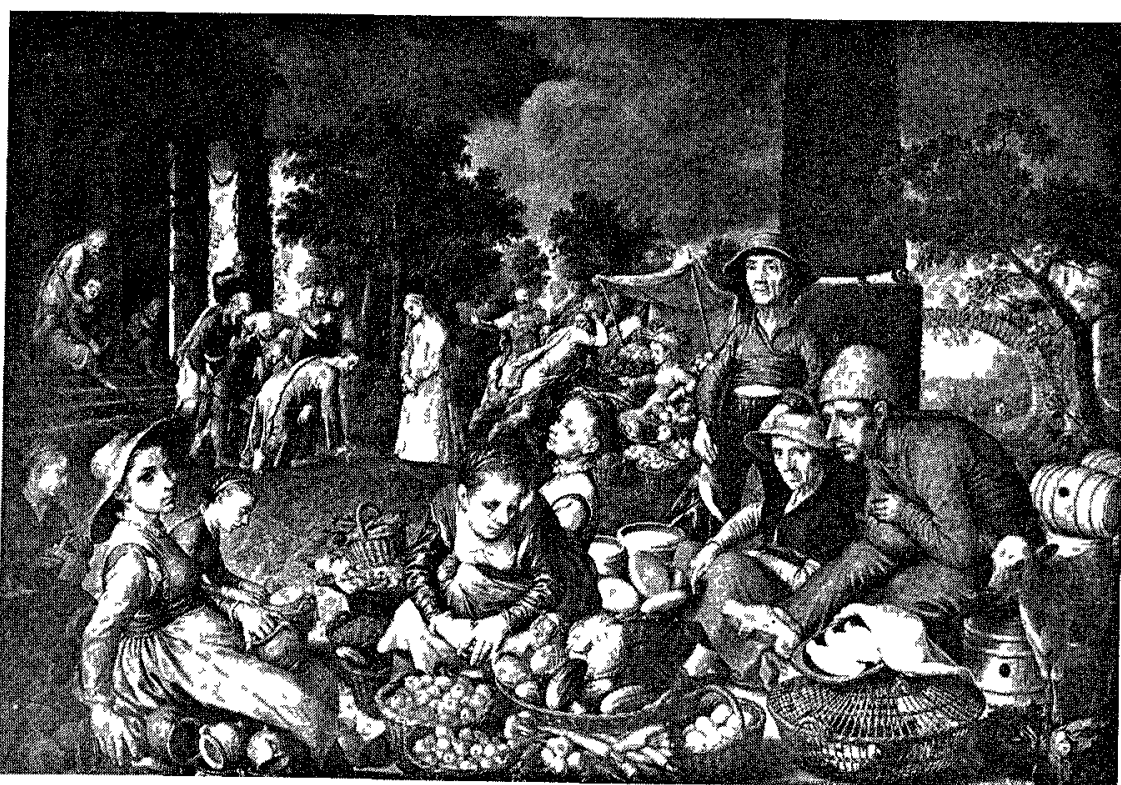

schilderkunst. Zoals hieronder zal blijken, acht ik deze laatste conclusie niet bevredigend; in elk geval staat het door Raupp bij Bruegel gekonstatcerde fenomeen niet op zichzelf en heeft dit duidelijk een antecedent in Aertsens boeren-voorstellingen. Maar als zodanig levert Raupps analyse van Bruegels werk een overtuigende indicatie dat 16 de-eeuwse kunstenaars in voorstellingen waarin boeren c.s. de hoofdrol spelen, uit zijn geweest op een welbewust thematiseren van stijl-en decorumkwesties en daarbij soms gebruik hebben gemaakt van een kontrastwerking tussen 'hoge' vorm en 'lage inhoud'.

Een andere aanwijzing dat zulks ook in het werk van Pieter Aertsen geschiedt, vormt een sch1lderij met de Aanbidding van het kind in Rouen (afb. 25). ${ }^{38}$ Het nakte Christus-kind is, met uitgestrekte armen naar de beschouwer gewend, gelegen op een overblijfsel van een antiek bouwwerk waarvon twee nog staande zuilen op de achtergrond te zien zijn. Blijkens de illustratie van de composiet-orde in Pieter Coecke van Aelsts uitgave van Serlio's boek over de Generale Reglen der Architecturen, die Aertsen hier getrouw heeft gevolgd, wordt het voetstuk waarop Christus ligt gevormd door een omgetuimeld kapiteel. ${ }^{39}$ Maria heeft een boers uiterlijk dat opvallend kontrasteert met de klassieke setting, hetgeen Buchan tot de uitspraak heeft gebracht: 'The same artust who had transformed kitchen maids into 'domestic royalty', has here created a Queen of Heaven with the features of a peasant. Yet all figures, heavenly and profane, share the same noblity of spirit.' 40 Men kan hier om twee redenen spreken van een intentioncel en inhoudelijk geladen stijl-kontrast tussen boers uiterlijk en klassieke zuilen-orde. Ten eerste is het geenszins de gewoonte van Nertsen om Maria altijd in een dergelijke gedaante voor te stellen. Dat het hier om een boers gezichtstype gaat lijdt geen twijfel: de jonge boerin in Aertsens Pannekoekeneters in Rotterdam (afb. 26), ${ }^{41}$ heeft precies dezelfde trekken, en ook haar vlezige handen zijn identiek van 
I8 Navolger Peeter Aertsen, Groentestal met de viucht naar Luypte, Genua, particulate versameling.

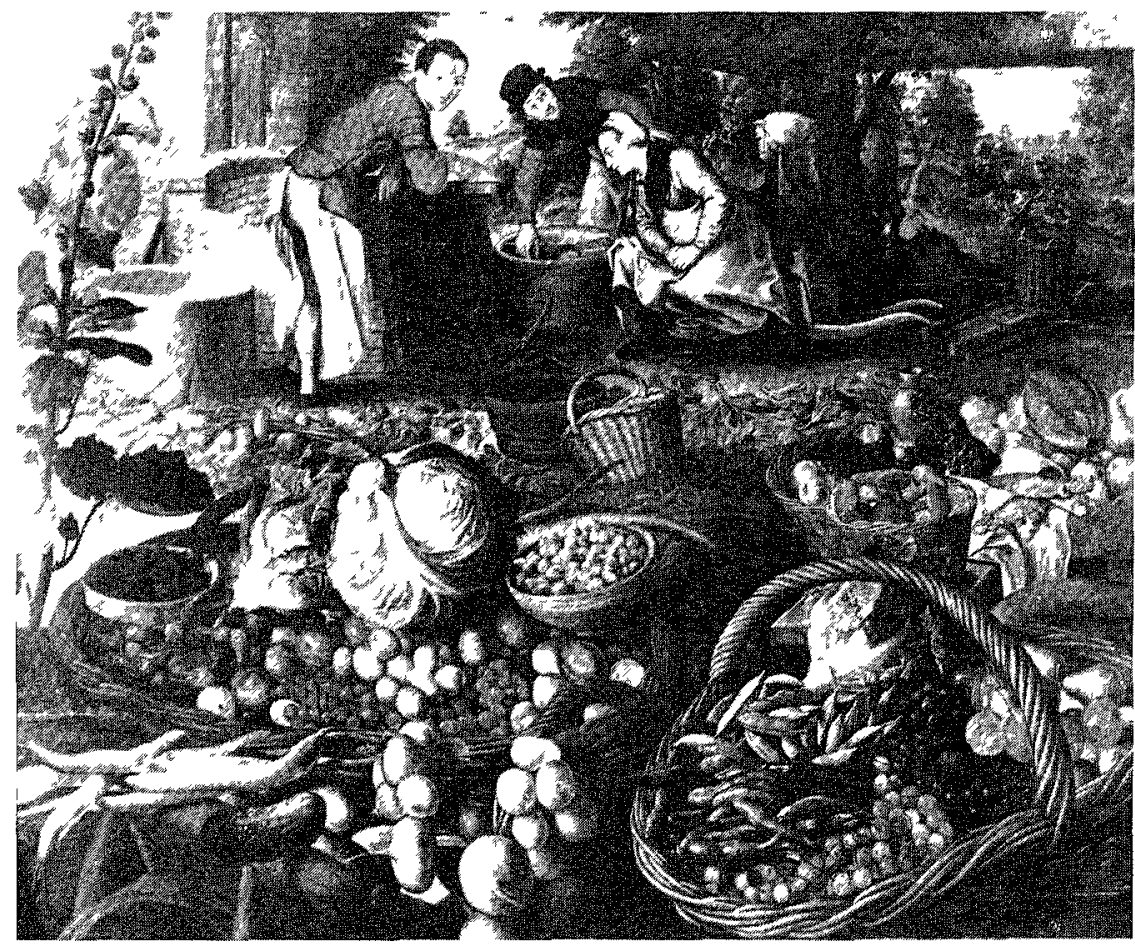

u1terlijk. Lien vergelijkbaar, hocwel minder geprononceerd boers uiterlijk heeft Maria in het Drieluike, mel de aanbidding der koningen in het Rijksmuseum te $\Lambda$ msterdam, en in de Aanbidding der berders in het $\Lambda$ msterdams Historisch Museum; langgerekte, sierlijke en meer bij de Italiaanse vormencanon aansluitende lichaamsvormen en gezichtstrekken daarentegen heeft Maria bijvoorbeeld in het Van der Buest-drieluike in $\Lambda$ ntwerpen, en in Aertsens altaarstukken met de Zeven Vreugden en Zeven Smarten in Zoutleeuw. ${ }^{42}$ Bij een dergelijke variatie lijkt de keuze voor het boerse type in het schilderij te Rouen intentioneel, en bepaald te zijn door het onderwerp: het lijkt uitdrukking te geven aan Maria's 'humilitas' die zo'n centrale rol speelt in laat-middeleeuwse denkbeelden over en voorstellingen van de menswording van Christus. Nertsens voorstelling van de Aanbidding in het Amsterdams Historisch Museum, waar het kind in de schoot van Maria is weergegeven, sluit nog duidelijker aan bij de 'humilitas'-symboliek in deze traditte. In Aertsens stuk te Rouen herinnert de plaatsing van het kind op het omgevallen compostet-kapiteel ter hongte van Maria's schoot aan dit beeldtype van de 'Madonna dell' Umiltà' dat in de context van Geboorte-scènes reeds bij Rogier van der Weyden voorkomt. ${ }^{43}$ De met paarlen bestikte diadeem die Maria in het haar draagt is tevens eigen aan de tradit1e van 'Madonna dell' Umiltà'- voorstellingen. Het motief verwijst naar Maria's verhcerlijking in de hemel als 'regina coeli', welke een gevolg is van haar deemoedige houding op aarde - ten teken waarvan $z$ ij, tegelijk met met haar nederige pose, vaak wordt voor-

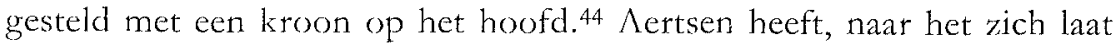
aanzicn, Maria het uiterlijk van een boerse 'regina coelı' gegeven juist om 


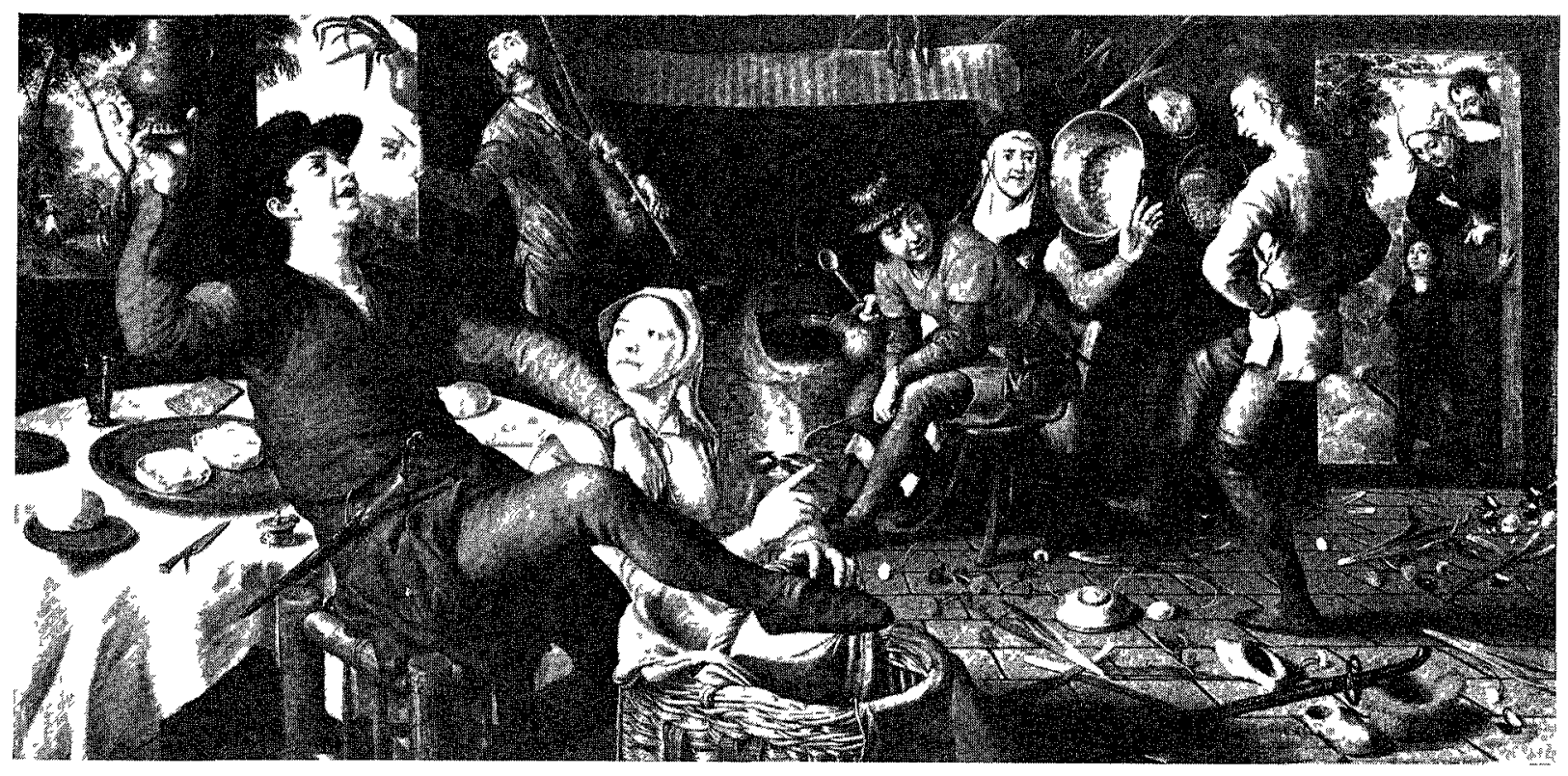

19 Pteter Aer/sen, De ezerdans, Amsterdam, Ryksmuseum. dexe paradoxale kombinatie van verhevenheid en nederigheid, welke inherent is aan het laat-middeleeuwse theologische concept van Maria's 'humilitas', conform de traditie door middel van een formeel kontrast gestalte te geven. Ook de ruine maakt deel uit van de traditionele Geboorte-ikonografie, en kan vanaf de is de eeuw verbeeld worden door Romeins-antieke overblijfselen; ze symboliseert het verval van de joodse leer en het heidendom door de komst van Christus, en de aflossing van het tijdperk 'sub lege' door het tijdperk 'sub gratia'. 45 Bij Aertsen moet de plaatsing van het naakte Christus-kind bovenop het ondersteboven liggende antieke kapiteel, dat met de erop uitgespreide dwaal fungeert als een soort altaar en daarmee de toekomstige passie in herinnering brengt, ${ }^{46}$ mijns inziens in het licht van deze traditionele ikonografie gezien worden als een direkt kontrast tussen de armoedige verschijning van het kind en de vervallen glorie van het antieke bouwsel. Het voormalige kapiteel diant nu als voetstuk voor de Verlosser, wiens naaktherd het stij-kontıast tussen $\not 1 j n$ boerse Moeder en de klassieke ambiance onderstreept. Moge in formeel opzicht de verhevenhend van de klassieke zuilen-orde een tegenhanger hebben in de nederige gedaanten der religieuze protagonisten, in inhoudelijk opzicht representeren dezen de wáre verher enhe1d, waarvoor het symbool van wereldse en uiterlijke luister chapeau bas speelt.

In samenhang met het voorafgaande mogen wij, meen $1 \mathrm{k}$, concluderen dat Aertsen in verschillende voorstellingen waar boerse typen een hoofdrol spelen, opzettelijk een 'lage inhoud' presenteert in een 'hoge vorm' en omgekeerd een 'hoge inhoud' in een 'lage vorm'. Dit vormt tevens een indirekte aanwijzing, dat Aertsen ook in zijn stilleven-komposittes, bij de enting van het grondschema voor de kompositie op het traditionele 'Andachtsbild', welbewust een 'eerbiedwaardige' presentatie- 
vorm heeft gekozen voor 'lage' motıeven ${ }^{47}$ Waar vootheen Maria en het kind de beschouwer in close up werden gepresenteerd, omringd door blocmen en vruchten waarvan de symboliek bovenal is gebaseerd op de hcmelse liefdesmetaforen van het Hoogled, daar eist nu de momumentale presentatie van allerhande aardse etenswaren dwingend de aandacht van de beschouwer op en wordt profane liefde geveld 48

Dat Aertsens stillevens een parallelle verschijningsvorm /1jn van de ideeen die aan $/ 1$ n boeren voorstellingen ten grondslag liggen, blijkt ook uit een vergelijkbare behandeling van individuele detals Net $/ 0$ min als 'realisme' een erg bruikbaar begrip is voor Aertsens boeren figuren, is het dat voor $/ 1$ n voorstelling van individuele stilleven motieven in tegen stelling tot wat alujd is beweerd ${ }^{49}$ Dere motreven stammen uit een vast repertoire en worden op een verrassend consistente wije in verschillende schilderijen herhaald 50 Zo komen exact de/elfde pompoenen en kalebassen, komkommers, druiventrossen, groene kolen en pastinaken ( de kolen en pastinaken bovendien steeds op dezelfde wije gegroepeerd ) voor in Aertsens Groentevcrkoopster in Berlijn (afb 20), de Marktscene mot (bristus in de overspolige vroum in Stockholm (afb 16), de Grocntestal in Stockholm (afb 2 I), de Groentcstal in Rotterdam (afb 22) en ten dele ook in de Koukenmol in Brussel (afb 23) Natuurlyk vormt een - althans voor dere groenten en vruchten eenmalige observatie van de visuele werkelijkheid de basis voor hun naturalistische weergave, maar de veelvuldige herhalingen maken toch duidelyk dat het Aertsen net om een dergelijke weergave als rodanig is gegaan, maar om de wije waarop dere motieven in de kompositie /1jn gegroepeerd lk vermijd hier het woord "komposi torische eenheld' of 'samenhang', omdat in elk geval in een aantal van dese schilderijen eerder sprake lijkt te $\iota_{1 j}$ n van een zorgvuldig geensce neerde kompositorische chaos Just omdat Aertsens marktscenes kunstmatige konstrukties 71 j en niet conder meer een blik op werkelijk bestaande marktstallen bieden, heeft de volgcnde obscrvatie alleen een rclatieve geldigherd

I $\mathrm{r}$ is een verschil te bespeuren in de wije waarop in de groentestal voorstellingen in Rotterdam, Stockholm en Berlijn de waar ligt opgetast, en de manier waarop bijvoorbeeld in een fragment van een marktscene met een Ecce homo voorstelling van Aertsen st. Munchen (afb 23) de goederen $/ 1$ in uitgestald ${ }^{51}$ Het laatste schilderij biedt ecn blik op een aantal marktkrainen, waar groenten en fruit, naast broden, kasen en wat vlees, vis en gevogelte, aan de man worden gebracht De produkten worden ter verkoop aangcboden in deselfde manden, vooral plattc en brede voor groente en frult, waarmee /1j/1jn adngevoerd, ook de produk tch van het veld $/ 1 j \mathrm{n}$ in principe per soort in aparte manden uitgestald, hoewel kombinaties van twee soorten in een mand bijvoorbeeld kolen met rapen, en bonen met framboren cveneens regelmatig voorkomen Juist in de kramen met dese waar neigen de manden op elkaar gestapeld te worden, waarb1j echter een rekere mate van over/1chtclykhe1d en orde gehandhaafd blift Dere wire van presenteren sct men ook vooral in de marktstal op de achtergrond in de Marketscunc te Frankfurt (afb i 7), 


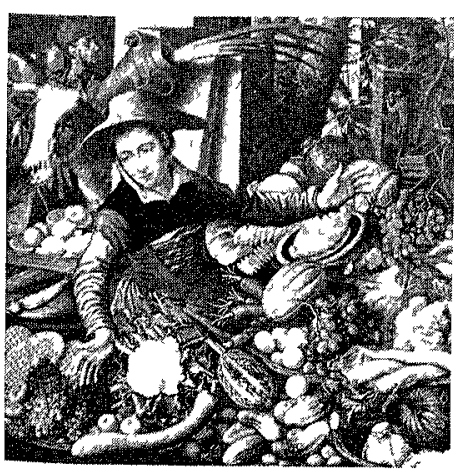

20 Pleter Aertsen, De groenteverkoopster, Berlyn-West, Gemaldegalere der Staatluche Museen Preassuscher Kulturbesztz.

21 Pieter Aertsen, Groentestal, Stockbolm, Hallnyl Museum.

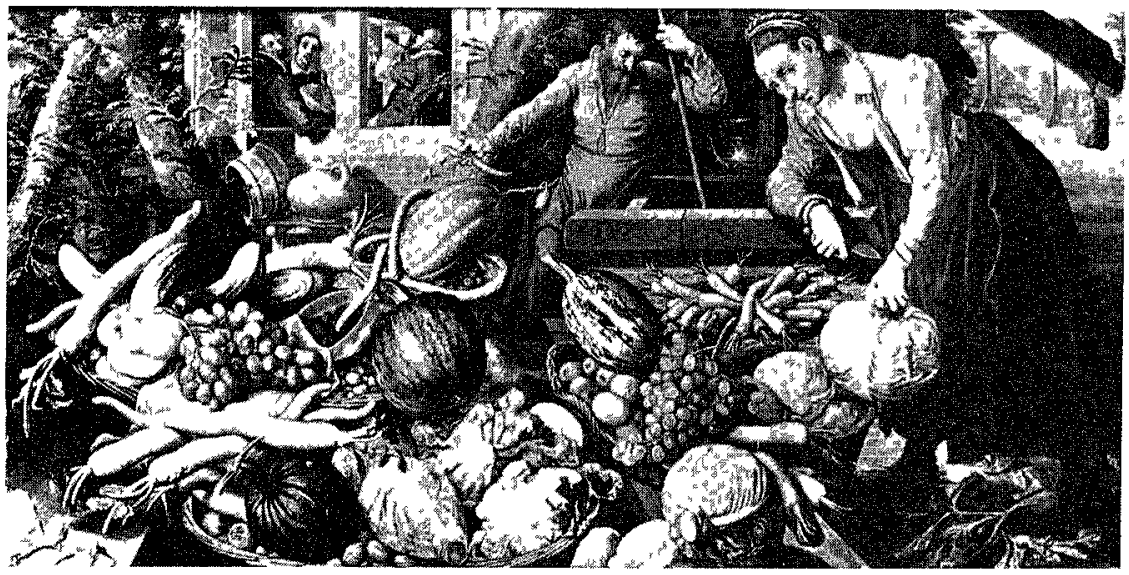

en geeft mogelijkerwijze de manier weer waarop groente en fruit op Antwerpense markten in de 16 de eeuw werkelijk werden uitgestald.

In elk geval is de uitstalling van de waar in de drie genoemde groentestal-voorstellingen van een geheel andere orde. Niet alleen liggen de produkten zonder rangschikking naar soort wanordelijk dicht opéén geprest en boven op elkaar gestapeld, maar maken ze zelfs, vooral in het schilderij in Rotterdam waar verschillende manden half zijn omgevallen, de indruk achteloos te zijn neergegooid (in het Berlijnse schilderij wordt de marketenster haast onder haar waar bedolven). Terwijl de precieze herhaling van individuele motieven toch getuigt van een zorgvuldige aandacht voor hun textuur en deze herhaling hun plaatsing in de kompositie tot een daad van weloverwogen rangschikking maakt, moet de groepering van deze motieven als geheel bij uitstek chaotisch genoemd worden. Een dergelijke rommelige kompositie lijkt onverenigbaar met de pretentie die Aertsen aan den dag legt door ook in deze voorstellingen terug te grijper op de 'eerbiedwaardige' presentatie-modus en het kompositie-schems van het traditionele 'Andachtsbild' - totdat men zich realiseert dat $\Lambda$ artsen in feite eèn 'boeren-kompositie', d.w.z. een door de marktlu1 zeif gecreëerde 'kompositie' van nederige produkten aan de beschouwer voorlegt. Is deze boerse chaos uit het oogpunt van de klassieke komponeerkunst (zoals bijvoorbeeld verwoord door Alberti) ecn flagranie schending van het decorum, in termen van het 'genus satiricum' mag de warboel passend genoemd worden. ${ }^{52}$ Het Rotterdamse schilderij bevat een nog verder gaande realsering van het principe van een 'hoge vorm' voor 'lage motieven'. In het centrum van de voorstelling ziet men een zittende boer wiens elegante, licht naar achteren neigende pose en lichaamsproporties duidelijke reminıscenties an Italiaanse voorbeelden bevatten (een precieze bron vermag ik niet aan te geven). Hij is gezeten op een baal met onbestemde inhoud: deze is geplaatst op een gekantelde kruiwagen, die op zijn beurt weer op een steen is neergelegd. In dit zorgvuldig opgestapelde bouwsel van onbeduidende voorwerpen, dat de boer een uitgebalanceerde zetel verschaft, is het pendant van de chaoti- 
22 Puter Aerisen, (toegeschreven), Groentestal, Rotterdam, Museum Boymans-van Beuningen.

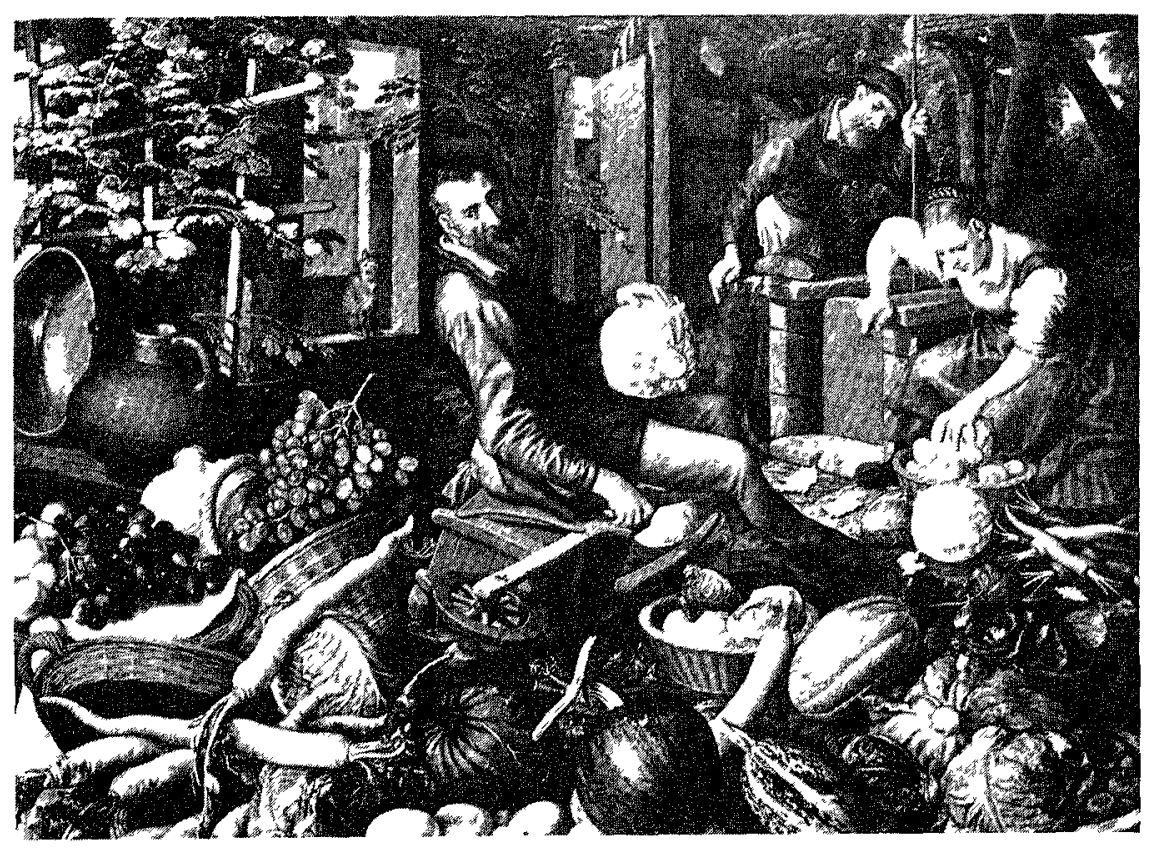

sche opeenstapeling van de groenten en het fruit te zicn, en is 'boerse kompositie-kunst' ad absurdum gevoerd.

De conclusie lijkt mij gerechtvaardigd dat aan $\Lambda$ ertsens stillevenvoorstellingen een zelfde principe ten grondslag ligt als aan zijn voorstellingen waarin boeren en keukenpersoneel de hoofdrol vervullen. Voor de voorstelling in haar geheel is telkens een 'hoge' kompositie-vorm gebruikt, gebaseerd op kompositie-schemata uit het klassiek-Italiaanse idioom en contemporaine religieuze devotie-schilderkunst; deze 'hoge' vorm dient de presentatie van 'lage' motieven. ${ }^{53}$ De kontrastwerking tussen vorm en inhoud die dit principe bewerkstelligt, is in verschillende schilderijen zo ver doorgevoerd tot in het detail dat hybride konstrukties onstaan waarin een ironisch element met betrekking tot de 'hoge kompositic-kunst "besloten lijkt te liggen. De gememoreerde chaotische stilleven-komposities en de houterige, verwrongen gestalte van de oude boer in het schilderij te Boedapest behoren tot deze ironische 'innerbildliche' kommentaren, en duiden samen op een weloverwogen gemeenschappelijke intentie van de schilder met deze schılderijen.

Alvorens te proberen de\%e intentie op een preciezere noemer te brengen, wil ik nog wijzen op één contemporain getuigents over Aertsen, dat de werk-en denkwijze van de kunstenaar die wij hier uit zıjn schilderijen hebben afgeleid, welıswaar niet met een schriftelijke bron staaft, maar als een these die de moeite waard is om overwogen te worden, kan helpen aanvaarden. Het betreft een getuigenis van Petrus van Opmeer (I 526 I594) in zijn postuum verschenen Opus cbronograpbicum orbis universi a mundi exordio usque ad annum 1611 (Antwerpen $16 \mathrm{II}$ ), dat handelt over een werk van de onbekende en misschien imaginaire schilder Johannes 


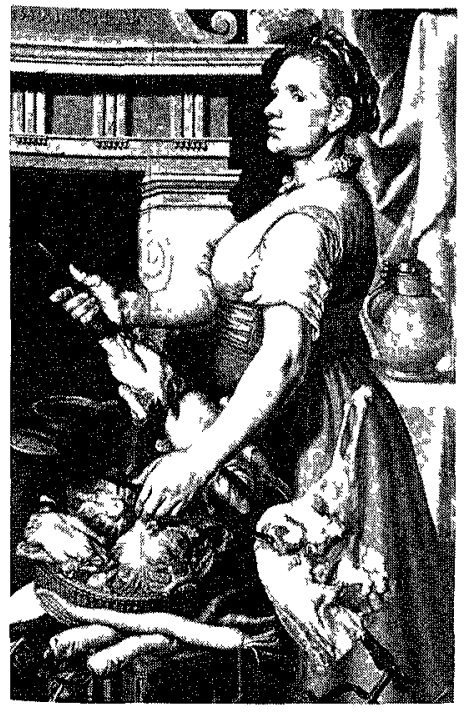

23 Pieter Aertsen, De keukenmeid, Brusel, Konmklyke Musea voor Schone Kunsten.

\section{'Alter Einoutus': Aertsens stillevenconceptie}

Einout, over wie Aertsen de loftrompet steekt: 'Florebat hac tum tempestate Roterodami Ioannes Einoutus, insignis quoque pictor, qui exemplo Moriae civis sui $D$. Erasmi provocatus pinxit tabulam ex albo CHRISTI affigendi cruci: in qua varij coloris atque diversae formae deformium hominum figurae conspiciebantur. Ita ut artificies in ea viderent errata omnium celebrium pictorum: videreturq[ue] ipse non modo artificibus, sed etiam illusisse arti. Hanc tanti aestimabat Petrus Longus pictor, ut mihi diceret eam non posse aestimari auro, sed insigni aliqua provincia. ${ }^{54}$ Weliswaar gaat het in deze passage niet over de kunst van Aertsen zelf, maar ik kan mij niet aan de indruk onttrekken dat de opzettelijke deformaties en de welbewuste, ironiserende schending van de traditionele kunst-canon die hij net als Einoutus lijkt te hebben nagestreefd, berust op overeenkomstige, zo niet identieke bedoelingen. Was deze 'tweede Piraikos' een 'alter Einoutus'? Belangrijk voor onderstaande poging Aertsens intenties nader te omschrijven is in elk geval de konstatering dat de idee van een schilderkunstige tegenhanger van Erasmus' Lof der Zotheid Aertsen vermoedelijk niet onbekend is geweest.

In moderne literatuurhistorische analyses van Erasmus' geschrift wordt benadrukt dat dit één van de meest geraffineerde creaties is geweest van een literair genre dat in de I6de eeuw zeer populair was: het 'paradoxaal encomium' - de paradoxale of ironische lofprijzing. ${ }^{55}$ Het genre gaat terug op een stijlfiguur in de antieke retorica en betreft een lofrede op onaanzienlijke, onwaardige en niet-lovenswaardige personen en zaken. Deze paradoxale lofrede maakt gebruik van dezelfde technieken die in de orthodoxe lofrede gebruikt worden om eerbiedwaardige zaken en personen te prijzen, zoals goden, helden, hooggeplaatste personen, landen, steden, maar ook beroepen, abstracta en zelfs dieren, planten en dode voorwerpen. Naast beruchte personen, zoals Helena of de tyran Phalaris, en bedelaars, bijen, muizen, een vlieg en jicht, vormen ook in het bijzonder zaken, zoals pannen, zout, rook en stof het onderwerp van antieke paradoxale lofprijzingen. ${ }^{56}$ In het algemeen volgen deze lofredes de topoi die in retorica-theorieën zijn ontwikkeld voor serieuze lofreden, waarin (b.v. door Quintılianus) voorschriften zijn ontw1kkeld voor de verschillende te prijzen eigenschappen en hoedanigheden, al naar gelang goden, mensen of dingen in het geding zijn. Zo betreffen de argumenten om dingen te prijzen - ook in de paradoxale variant - gewoonlijk de ouderdom, de waardigheid en de bruikbaarheid der objecten. ${ }^{57}$ De functie van de antieke ironische lofprijzing - ook in zijn neergeschreven vorm - is de oratorische vaardigheden van de redenaar te etaleren en hem hiervoor de bewondering van het publiek te doen oogsten. In de renaissance verwerft het genre een grote populariteit en wordt het vooral door humanisten in Duitsland, de Nederlanden, Frankrijk, Italië en Engeland in het Latijn, maar ook in de landstaal gecultiveerd - steeds met een beroep op antieke voorbeelden om het schrijven van dergelijke triviale literatuur te rechtvaardigen. ${ }^{58}$ Doch ondanks de onbeduidendheid van het genre in de literaire hiërarchie heeft men de - geheel volgens de regels van de klassieke 'declamatio' vervaardigde - ironische lofrede in deze tijd een serieuze 


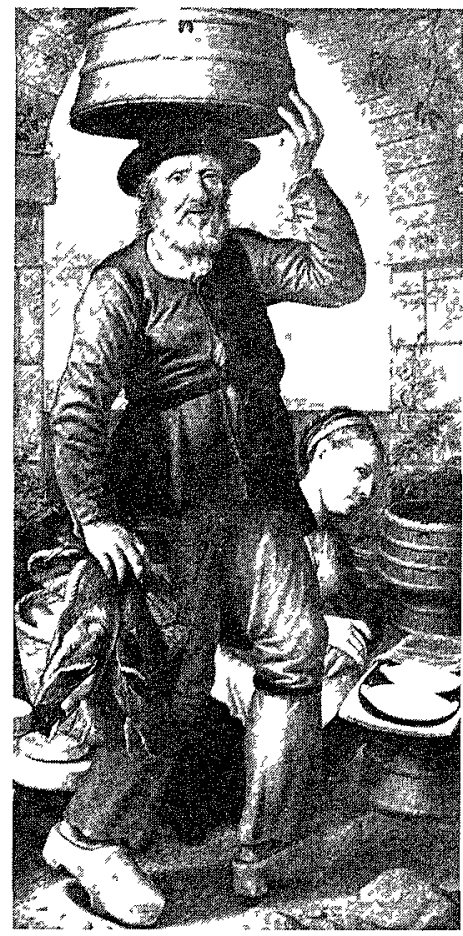

24 Pleter Aertsen, Marktcrene met boer, Boedapest, Museuns poor Scbone Kunsten.

2) Pueter Aerlsen, Aanbuddung der berderr, Rouen, Musée des BeanxArts.

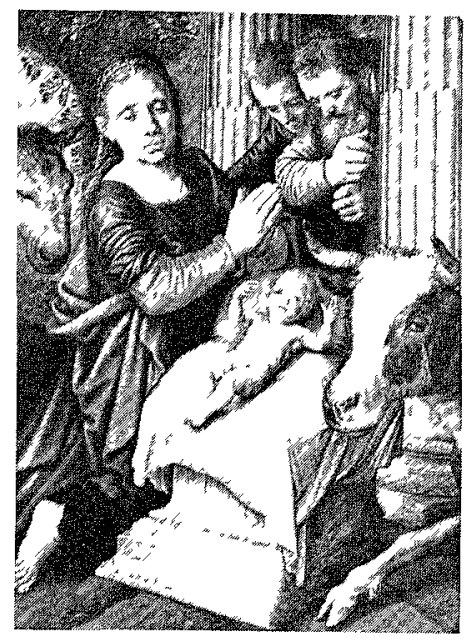

functie toebedeeld. Of het nu gaat om de lofprijzing van nederige en onwaardige zaken, ja zelfs verderfelijke dingen, dwaasheden en zonden, steeds heeft men daarbij de belering van de lezer op het oog. De ironische lofprijzing dient vaak als het indirekte middel, als de omweg waarlangs men poogt de belering te verwezenlijken. De lovende bewoordingen waarmee een zaak wordt aangeprezen die volgens de gangbare opinie onwaardig is, moreel slecht of anderszins niet-lovenswaardig, dienen ertoe de lezer, in de ban van de vaardigheid van de spreker/schrijver, als het ware op het verkeerde been te zetten en hem te laten instemmen met het aangeprezene om hem vervolgens het bedenkelijke gehalte van deze instemming en zijn eigen geneigdheid tot dwaasheid en zonde te laten inzien. Tot dit inzicht komt echter alleen de goede verstaander, de lezer die begrijpt en erkent dat hij zelf impliciet het voorwerp van ironische kapitteling is; in expliciete termen geschtedt de belering niet. Het is deze techniek van het verleiden van de lezer tot instemming met iets wat niet-lovenswaardig is, ter relevering van de morele gesteldheid van de lezer zelf, dıe ook Erasmus gebruikt om de dwaasheid als een algemeen menselijke eigenschap ironisch te prijzen en te ontmaskeren als een doorn die een ieder, dus ook de lezer, in deze of gene vorm in het vlees steekt. J acht de lezer om de dwaasheden waarover Vrouwe Moria de loftrompet steekt - en Lirasmus legt het daarop aan -, dan treft zijn spot hemzelf. Zo is wel gezegd dat de ironische lofprijzing alleen bestaat en functioneert bij de gratie van het vervullen door de toehoorder/lezer van de - (dubbel)rol die hem in deze stijlfiguur is toebedacht. ${ }^{59}$

De Amerikaanse literatuurhistorica Colie heeft als eerste een (globaal) verband gelegd tussen het I 6de-eeuwse literaire genre van het paradoxaal encomium en het in dezelfde tijd ontluikende genre van het geschilderde stilleven een suggestie dic naar het schijnt geen enkel spoor in de kunsthistorssche vakliteratuur heeft nagelaten. ${ }^{60}$ Colie ziet een parallel tussen deze twee genres op grond van het feit dat beide triviale zaken tot onderwerp van beschouwing maken, en er in beide een element schuilt van wat $\varkappa$ ij 'self-reference' noemt: een nadruk op de technische vaardigheden van de redenaar/schilder en de aantrekkelijke presentatie van deze zaken, bedoeld als die zijn om als zelfstandig object van bewondering gerecipieerd te worden. ${ }^{61}$ Tevens wijst zij erop dat Rabelais, wiens boeken over Gargantua en Pantagruel verschillende paradoxale encomia bevatten, zichzelf vergelijkt met de antieke 'rhyparographus' Piraikos, met wie ook $\Lambda$ ertsen in zijn tijd is vergeleken.62

De suggestie van deze parallellie heeft, mits men haar nader specificcert, een uitgesproken waarde voor de interpretatie van Aertsens stilleven-conceptie. Weliswaar kan men uit de korte anecdote bij Van Opmeer niet opmaken, of Aertsen Iirasmus' boek gelezen heeft en hieruit kennis omtrent de retorische principes van het paradoxaal encomium heeft geput. Maar naar mijn mening zijn de overeenkomsten tussen de retorische stijlfiguur en de geanalyseerde werken van Pieter Aertsen zo groot dat wij in deze stijlfiguur de bron mogen vermoeden voor de conceptic van zijn stilleven- en boeren-voorstellingen, bepaald als zij is door een 'hoge, 


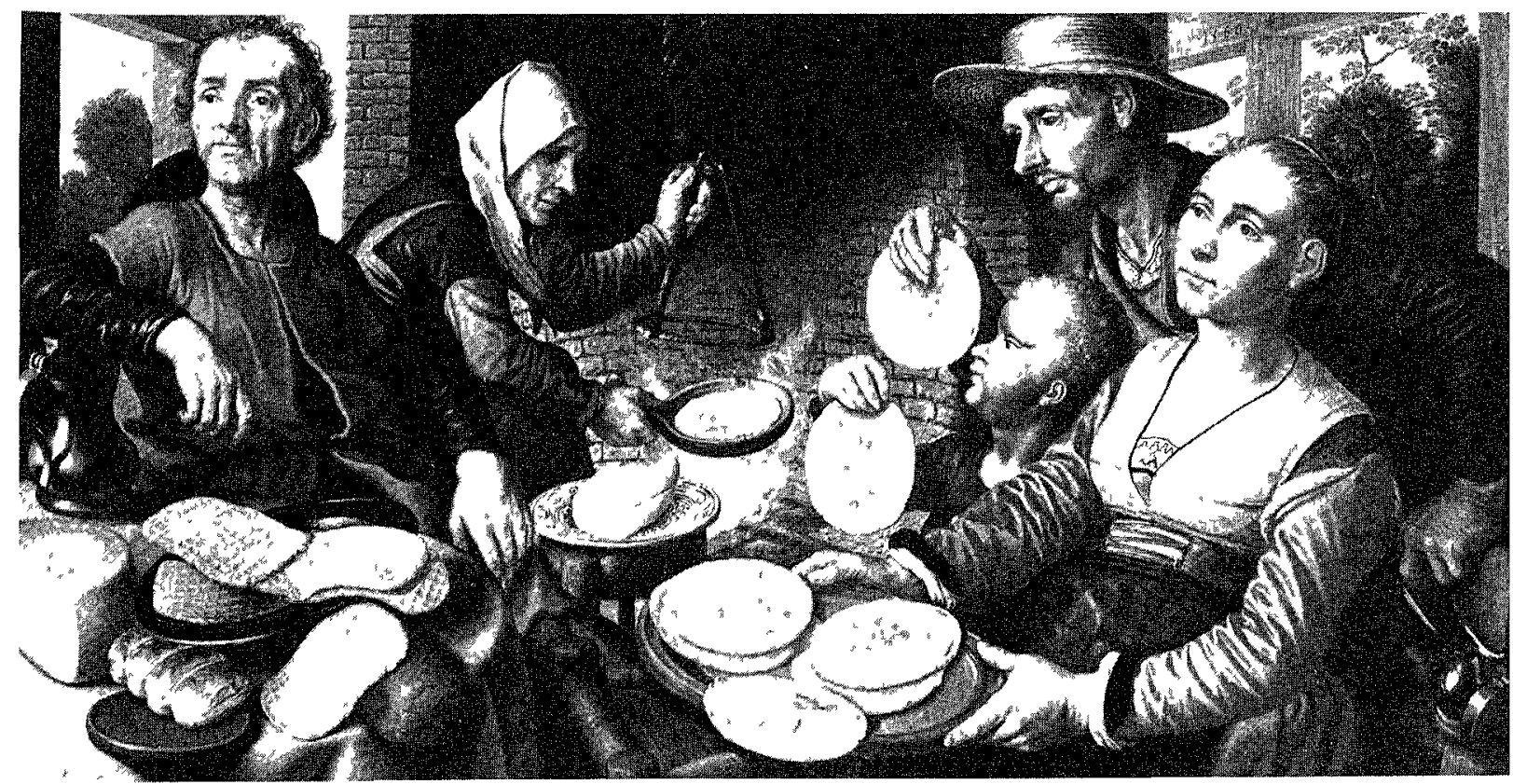

26 Pletur Aertsen, De pannekoekenbakster, 1560 , Rotlerdam, Museum Boymans-van Beuningen. eerbiedwaardige' presentatie van 'nederige' voorwerpen met hun platvloerse symbolische lading. Wanneer wij ervan uitgaan dat deze voorstellingen als schilderkunstige paradoxale encomia geconcipieerd zijn, vindt niet alleen de geschetste discrepantie tussen vorm en inhoud een plausibele verklaring, maar is ook een basis gelegd voor een juist begrip van de functie van deze schilderijen. Niet alleen kan de nadruk op de technische vaardigheid van de kunstenaar bij zijn weergave van allerhande groenten, frutt, vleespartijen etc. begrepen worden als bedoeld om de bewondering van de beschouwer te oogsten, maar kunnen ook de rronische 'innerbildliche' commentaren op de schending van het decorum van de 'hoge kunst' beschouwd worden als bij de stijlfiguur van het paradoxaal encomium passende bravourstukjes. Tegelijkertijd kan men ook de moraliserende functis die men Aertsens schilderijen gewoonlijk toeschrijft, verklaren als goworteld in deze stijlfiguur, en bovendien de specifieke methode die Aertsen gebruikt om zijn publiek te beleren tot dezelfde bron herlexden. Deze methode kan omschreven worden als een verleidingstechniek, die vergelijkbaar is met Lrasmus' methode om zijn lezers tot belcring en zelfkennis te brengen. Het huidige bestek laat mij alleen toe de laatste stelling aan de hand van enkele korte voorbeelden te illustreren.

Raupp heeft erop gewezen dat er in het Boeren-feest in Wenen (afb. 4) ecn ambivalentie schuilt in de onderlinge relatie tussen boeren en burgers in de voorstelling zelf, en in de relatie tussen de op de voorgrond afgebeelde boeren en de beschouwer. ${ }^{63}$ In deze boeren moet men volgens Raupp vertegenwoordigers zien van de zonden van de onmatigheid en de wellust. Zij zitten aan een tafel die gedekt is met glazen en ander gerei, welke alleen voornamere personen in deze tijd gewend zijn geweest te 
gebru1ken; bovendien maakt de afsnijding van de tafel door de onderste beeldrand de (burgerlijke) beschouwer als het ware tot een imaginarre disgenoot. De distantie tussen boer en burger, waarvoor in andere $16 \mathrm{de}-$ eeuwse voorstellingen van boeren-feesten - in het beeld zelf zowel als in onderschriften bij grafische voorstellingen - steeds wordt gewaakt, is op de achtergrond duidelijk opgeheven, zoals trouwens vaker voorkomt in schilderijen van Aertsen. ${ }^{64}$ Volgens Raupp dient deze achtergrondscène als moraliserend-didaktısch kommentaar op de voorgrondscène, en fungeert ze als een waarschuwing voor de gevaren die diegene bedreigen die zich met zulk boers gezelschap afgeeft. Ik weet niet zeker of $1 \mathrm{k}$ Raupp enigszins onrecht doe, wanneer $1 \mathrm{k}$ 71jn uttleg op één lijn stel met de waatschuwende functie die andere kunsthistoric1 Aertsens boeren- en stilleven-voorstellingen toemeten. Zo gaat er ook volgens Irmscher een waarschuwing van zijn markt- en keukenstukken uit om nte $t$ te zondigen en om geen gemene zaak met de boerse personificaties van de zonde te maken, hoeveer de voorstelling de beschouwer hiertoe ook uitnodigt met de aanlokkelijke waar die de boeren en marktlui hem aanbieden. ${ }^{65}$ Naar mijn mening echter ligt de zaak net iets anders. De achtergrondscène in het Boeren-feest in Wenen maakt expliciet wat in de voorgrondscène impliciet besloten ligt, namelijk dat de verbroedering tussen boeren en burgers, nolens volens wellicht voor zover het de beschouwer betreft, reeds plaatsgevonden beeft. Wanneer de beschouwer zou menen in moreel opL1cht verre van het gedrag der boeren te staan, maakt de voorstelling hem - althans de goede verstaander - duidelıjk dat deze distantie schijn is. De zorgvuldig gedekte tafel is \%o weergegeven, dat de beschouwer onw1llekeurig de disgenoot der feestvierders 1s; en wanneer hij zich vrolijk maakt over het gebrek aan decorum dat de boeren aan deze tafel vertonen, is het de identificatie met 'zijn' tafel en de hier geldende manteren die hem inderdaad met hen doet aanzitten. ${ }^{66}$ De verklarende en belerende functie van de achtergrondscène geldt slechts die beschouwer die zichzelf een dwaas weet. Op zelfde wijze moet, dunkt me, de tot zelfkennis van de beschouwer leidende verleidingstcchniek van de stilleven-komposities geinterpreteerd worden. Wanneer men de schilderkunstige kwaliteiten van deze werken bewondert, laat men zich onwillekeurig ook tn met de personen die de groenten, fruit en vlees e.d. aanbieden. De gebaren waarmee $z 1 j$ de uitgestalde waar aanprijzen en de beschouwer uitnodigen tot inspectie daarvan, maakt dat de beschouwer - ook al meent h1) dat ziyn interesse alleen zuvere en hogere (kunst)intenties geldt door het betasten met het oog van deze waar de facto het hem aangebodene accepteert en $/ 1 \mathrm{ch}$ daarmee automatisch compromitteert. ${ }^{67}$ Ook hier lijkt de achtergrondscène te fungeren als "explicatief voor de goede, d.w.7. L1chzelf kennende verstaander, om het even of deze scène nu profaan dan wel religieus van aard is. Het kussende paar op de achtergrond van de Groenteverkoopster in Berlijn (afb. 20) is een zinnebeeldige unbeelding van de 71nnelijk-visuele omarming van het aardse goed waartoe de voorstelling elke beschouwer onontkoombaar verleıdt. En de scène van Christus' terechtw1jzing van de farizeeess op de achtergrond van de Marktscine met 


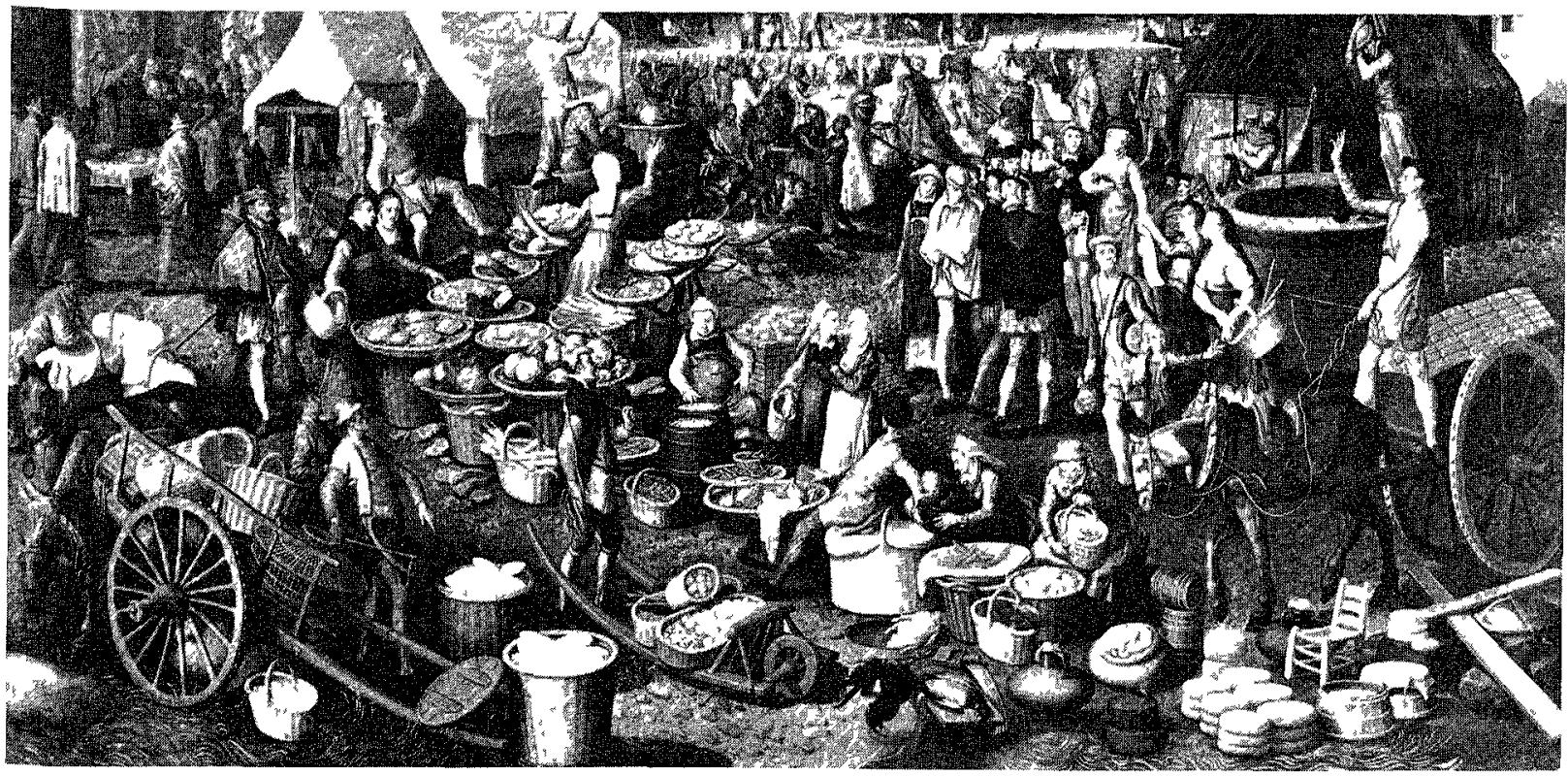

27 Pueter Aerisen, Marktscène met. Ecce Homo (fragment), Munchen, Bayerisches Staatsgemaldesammlungen, Alte Pinakotbek.
Christus en de overspelige vroum in Stockholm (afb. I6) - 'Wie van u zonder zonde is, werpe het eerst een steen (...)' (Joh. 8; 7) - zal zijn bedoeld om de beschouwer erop te wijzen dat in feite het alloo1 van zijn eigen moraal in het geding is, i.c. de 'voluptas oculorum' - en dus ook de 'voluptas carnis' - waarin de voorstelling hem heeft verstrikt met de waar die de marktlui hem uttnodigend voorhouden. ${ }^{68}$

Tot slot een woord over het paradoxaal encomium als schilderkunstig 'genre' in de i6de eeuw. Er is voorshands geen reden om aan te nemen dat Aertsen de eerste en enige zal zijn geweest die deze retorische stijlfiguur in de schilderkunst heeft beproefd. 'Einoutus' is reeds gememoreerd, maar sommige schilderijen van Bruegel waarvoor dezelfde discrepantie tussen klassiek-Italiaanse vormencanon en boerse thematiek is gekonstatcerd als voor Aertsens werken, zouden als realisaties van dezelfde stiilfiguur kunnen zijn geconcipieerd. In dit licht zou wellicht ook Jan van Hemessens Bordeelscène met de Verloren Zoon in Brussel (afb. 3) herbezien kunnen worden. Immers hier heeft Aertsens 'lenen' van het kompositic-schema van een traditioneel ' $\Lambda$ ndachtsbild' voor de schildering van personificaties van allerlei zonden een precedent. En de complexc, gracieuze bewegingen waarmee de courtisanes in dit schilderij de als I 6de-eewse burger vermomde - Verloren Zoon inpalmen, doen denken aan de wurggreep van de slang in de beroemde Laocoön. ${ }^{69}$ Dit soort schilderijen kan Aertsen tot voorbeeld zijn geweest bij het aanwenden van de beeldtaal van de klassieken en de Italiaanse renaissance voor komposities met 'lage' onderwerpen. In elk geval zou, áls er bij nader onderzoek sprake zou blijken te zijn van de door verschillende kunstenaars gepraktizeerde stijlfiguur van het paradoxaal encomium, dit 'genre' geen zelfstandige status moeten worden toegemeten; het zal slechts één der uitingen van het heterogene 'genus satyricum' geweest zijn. ${ }^{70}$ 
1 Lie Jan Muylle, 'Picter Acrtsen on Joachim Beuckelner in de kunstliteratuur (ca is $60 \times 610)^{\prime}$ (at tent Gcrt $998687,14 \times 7$

2 / 16 o 2 Baldass 1923 , 19, M J I ricdlandcr, Lssays uber do Landscbaftsmalerer und andere Bildgattungen, Den I laag 1947,24 106 cn I9 $210,1 \mathrm{~h} \mathrm{~b} 197$ 198, them, farly Nether landish Pantmo XII, Leiden Brussel 1975, 59 60, cn Moxcy $1976 \mathrm{~B}, 1$ h b 137 Is9

$3 / 10$ Grosjcan 1974 , $\Gamma$ mmens 1973 , en voor de antithetische grondstructuur van Aert sens en Beuckclacrs markt en keukenstukken in het algemcen Falkenburg i $988 \mathrm{~B}$

4 /ic voor dere intcrpectatic I mmens 1973 en vooral Irmscher 1986, 2 ig 232

5 Stcrling i $959,5 \mathrm{fr}, \mathrm{II}, 38$ 4

( Plinius, Naturales Historia XXXV, ir 2, /c noot $53 \mathrm{cn} \mathrm{vgl} \mathrm{noot} 54$ Lic resp Iloogcwerff IV/r94I 42, s r2, en D I recdbcrg I $987,22424 \mathrm{I}, 1 \mathrm{~h} \mathrm{~b} 229 \mathrm{ff}$ en $236 \mathrm{ff}$

8 Sterlings these 15 onderschecven door 1 II Gombrich, "Tradition and 1 xpression in Wcstern St1ll I if ' Mcditalions on a Hobby llorse, I onden 1978 (3), 95 ros, en hceft tcven cen positicf ccho ontvangcn bi1 Moxcy 1977 A, 27, en bij Raupp 1986, 310

$9 / 1 \mathrm{c}$ Scgal I 988,26 28, en $\Gamma \mathrm{M}$ Kivaler, "T rotische clcmenten in de markttafcrelen In Bcuckelacr, Acrtsen ch hun tijdgcnoten', (at tent Gent 198687,1826

10 Vgl voor dit gevocken van ongerimatheid 11 Miedema, 'Realism and comic modc the pcasint, fimolus 9 (1977), 20 ff Uit ecn dergelifk opvatting van ongcrijmdherd kom1 m i Moxey s afwijang van cen dieperc in van Aertscns stilleven moticven voort / Moxey I $976 \mathrm{~B}$ cn Moxcy $1977 \mathrm{~A}$

11 Lie o M Miticr I941, 91ff, Rupp 1986, 217, cn ( at tcnt Amsterdam 1986, 344

12 Brussc], Kon Musca voor Schone Kunsten, anv nr 2838

13 Pictcr Aertscn, Vlecsslal mut de Vlucht naar I gyple (155I), Uppsala, Unversitcts Konst samling, inv nr L I, 1dcm, Stalleven mut Christus un bet buts van Maria on Martha (1552), Wencn, Kunsthistorisches Museum, inv nor 6927

14 Picter Acriscn, Bocren farl (1550), Wencen Kunsthistorisches Museum, inv nr 2365 , Rrupp i 986, p 2 I 7

1) Ie A Riegl Das bollandiscbe Cruppenportral, Wenen 1931 107, Raupp 1986, 216, vgl Moxcy $1977 \Lambda, 20$

ir Quinten Massys, Marza on kend, Bcrlin Dahlem, Gcmaldegalerie der Stratlichen Mu secn, inv nr $56 \mathrm{I}$ / $\mathrm{M}$ J 1 riedlander, I arly Nutberlandish Paining Vll, I ciden Brusucl 1971, nr 18, Idem, Mara in kind (1529), Parijs, Musce du l ouvre, inv nr 2030A lbid, nr 24, Barend van Orley, Mara on kend, Madrid, Musco del Prido, inv nr 1932 M J I ricdlandcr, I arly Natherlandish Panting VIII, I caden Brussc] 1972, nr 132, 1dcm, Maria on kend (1522), Madrid, Museo del Prado, inv or 2692 sbed, nr 140, Joos van Cleve, Mara cn kind en de ll Anna, Modena, Galkrid I stense, unv or r65 M J I ricdlander, Farly Netherlandasb Pabnting IXa, I eiden Brussel i 972 , nr 45, kckm, Kcrsenmadonna, $\Lambda \mathrm{kcn}$, Sucrmonde Muscum ebed nr G3a

17 Picter (oecke vin Nelst, HI I amulu, Brugge, coll Joly 10 Marlicr ro66, 238 (vis] o m de figss 176, 179, 195, 198), Idcm, Mariacnkind, Musce (urtius ibad, p 244, Jan van Hemcssen Marka en kend, Brugge, Groeningcmuscum, nv nr 232 AC Wallen r983 cat $\mathrm{nr}$ 14, 1dcm, Marka $n$ kend (1543), Madrid, Musco del Prado, 1nv nr I542 ibid, cat nr 25

18 I lder heb ik de 1 Gdc ceuwse traditic van het kompositie type 'Andachtsbild' mot con of meer nevenscencs getracerd tot het werk van Rogic van der Weyden cn IIns Mcmling $71 \mathrm{C}$ alkconburg $1988 \mathrm{~A}$, I 837

1) Picter Aertscn, Shlleven mu Cbrastus an bel bus van Marla en Martha, Rotterdam, Mu seum Boymans vin Bcuningen inv nr I ro8

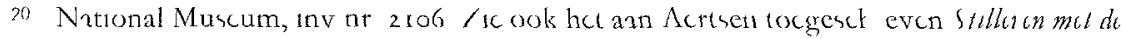
maaltigd in I mmaus, vooim coll V Bloch

21 De dingonale plaatsing van de /uilenrij hocft nict te /ijn ingcgeven door het dircke voorbecld van Jon van Flcmessens Bordedsceme in Brussel (afb 1), matr kan ook cen voorbceld hebben gchad in 'Andachtsbilder' met Marin in het kind, of een hellige, 
b v in het weth van Qunten Massys - /c I riedlander VL/1971 (noot I6), nrs i 8 a (P1 23) en 35 (P1 39)

22 Markescenc mot Cbristus on de overspelge vrotw (i 59 ), Irankfurt, Stadelsches Kunst-

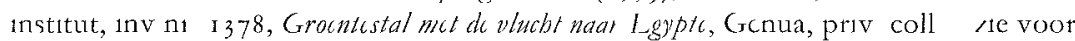
de verschillende vaianten van dese hompositic Cat tent Gent $198687, \mathrm{n1}$ i 8 ( $1 \mathrm{~h} \mathrm{~b}$ noot I), en Buchan 1975,220 , cat nr 54 In tegenstelling tot de opinie die 15 gevent1 leesd in de Gentse tent cat, I42-143, mecn $1 \mathrm{k}$ dat dere kompositie wel degelijk teruggaat op een inventie van Aertsen $/$ elf

23 Luerdans (I 5 2), Amstcidam, Rifksmuscum, inv nr 5, Grotnteverkoopstu (1567), BerlinDahlem, Gemaldegalcrie der Staatiche Museen, inv nt 3/6x, Grocntestal (i 569 ), Hallwylska Musect, cat nr B 20 , Grocntestal, Rottetdam, Muscum Boymans-van Beuningen, 1nv, nr 2536 Zie Raupp 1986, 217 voor de 'cxplicaticve' functic van de achtetgrondscene, vgl Wuyts $1987 \AA$, $209 \mathrm{~A}$, die de achtergrondscenc in Acrtsens Hennetaster in het Kon Mus $\mathrm{v}$ Schone kunsten in Antwetpen een relfde functe toc schriffe

24 Lie voor ecn dergelıhe duding, naast de hieionder genoemde auteur', J Held, 'Dr Fricdlander's Scholarly Study of Jatly Tlemsh and Dutch Painting', Art in America 27 (1939), 8I-82- mct instcmming anngehaald doo1 Buchan 1975, I47 I48

25 Keukenmted (1559), Brussel, Kon Mus voor Schone Kunsten, inv n1 705 Zic Grendl 1942, I50, 154, Gcnalle 1954, 278 (vgl 280, waa1 geregd wordt dat Aettsen het profane onderwcrp 'noblesse, l'cmouvante majeste' yceft), en Buchan 1975, I46-147

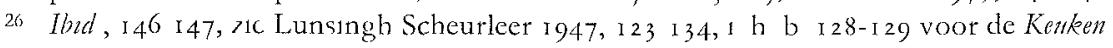
medd in Brussel Vgl Genalle 1977, i 2 Vgl ook /loogewerf IV/r941 42, 534, dic crop wees dat de datcting van dit schildci11, wclke op de schouw leesbaan 19- 'i 599 i6 Cal Aug' (d w, 17 jul1 1559), is op 'anuck-tomeinsche wijre'

27 Buchan 1975,147

78 Genalle I954, 277 en 279

29 Pieter Aetscn, Botr in con nis ( I 61), Boedapest, Srepmuvesect1 Murcum, inv n1 673 Sievers 1908, 91 92, Buchan 1975, i 57, telatcert de homposite in dit schildci1] aan Rosso's prenten van goden ( $B$ XIV 220, 114 ) cn Mareantonio's pienten van allegorische figuren (B XIV 213, $274 \mathrm{cn}$ XIV 214, 276) Moxey 1977A, 59, n I, w11st op de 'waatdighetd' van de figuut van de bocr, welkc hij in kontiast /et met satirische en lomische voorstellingen van boeten bij Albtecht Durer

30 Zic ( van de Velde, Irans I lors (1519/20-1570) I even (n Wrerken, Bussel i975, afb I 7 I en 268 , vgl afb 219

$317 \mathrm{cc} b \mathrm{c}$ ibid, afb $221 \mathrm{cn} 242$

32 Ibul, afb 68

33 Lic voor het volgende Raupp 1986, passem, madt th b goff, i 26 I 33 en $310-316$

34 Lic de bock besptching van P Vandenbiocck in S imıtolus 18 (1988), 69-73

$35 \mathrm{Vgl}$ Raupt i 986,304 ff Vandenbroccls diangt gecn bewijen aan voor $/ 1$ n opvatting als sou Rrupps thcse onjust /jn Grond voor $/ 1 j \mathrm{n}$ afw1//nng $1 \mathrm{~s}$, dunkt me, het feit dat de/c these een $7 \mathrm{ces}$ bewuste omgang met cen stipl of genusbegup implicceit, dee precier het tegendecl inhoudt van Vandenbroceks eigen these, nl dat het boerengent i ontstaan is uit cen net bomm/ gestuut de behoefte van de stedelijkc buigetij in de

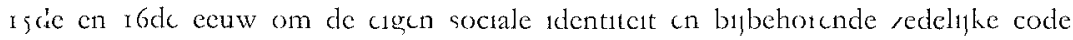
'regatief' te defineten met voorstellingen van de matschappelyj-'andetc' se de

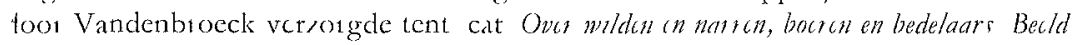
van de andere, vertoog over bei zall, Antwcipen (Kontnllijh Muscum voot Schone Kunsten) $1987, v g 1$ P Vandenbrocck, Jherommuls Borch tursen volkelewen en stadscullum, Ber chem 1987

36 Raupp 1986, 214223

37 lbed, 29I-299

38 Rouen, Musee des Bcaux- $\Lambda \mathrm{rts}$, inv nr $07 \mathrm{I}_{4} 4$

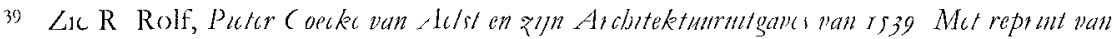
'Du Inventue der coloninun' en 'Generale Reg/en der Archtectmen', Amstetdam 1978, P IIIlv (Bk IIII cap IX), en voor anderc ontleningen van Aertscn aan Serlo, Lunsingh Schcurlect 1947 
40

(1) kind, en voor het 'humilitas'-motief in dese traditie G Schilier, Iconography of Christian
Art I, London $197 \mathrm{I}, 7^{6-84}$, vgl M Mers, Paning in Horcnce and Siena after the Black Duath, New York ig64 (I ed I951), r32-I 56

44 Reeds in Stephan Lochners Madonna in do rosenium in Keulen is Maria met een paarlen kroon in het haar afgebeeld - vgl It M Vetter, Maria im Rosenbag, Dusseldorf 1956, de titelplaat en afb i 8, 20, 2 I, 23 Zie voor de verwevenheid van Maria's 'humilitas' met haar verhevenheid tbud, p 19, en Meiss 1964 (noot 43), r 53 f, vgl 1dem, 'IIIghlands' in the Lowlands Jan van Lyck, The Master of Flemalle and the Franco Italian 'Tradition', Gazette des Beaux-Arts 57 (196r), $275 \mathrm{ff}$

45 Z1e Schiller 197 I (noot 43), 81-82, en F Panofsky, Early Netherlandash Paintang Its Origen and Character 1, New York $1971,134 \mathrm{ff}$

46. Vgl B G Lane, 'Ecce Panıs Angelorum' The Manger as Altar in Hugo's Berlin Natwuty', Art Bulletin 57 (1975), 476486

47 De 'Romeinse', 'heroische' monumentaliteit van Acrtsens stilleven-komposities is benadrukt door o a Friedlander XIl/1975 (noot 2), 60-61, en Sterling 1959, 44 en 56 , vgl Freedberg $1987,229-230$ en 236

48 In een aparte boek-publikatie die $1 \mathrm{k}$ momenteel in voorberciding heb zal ik uitgebreid ingaan op de hemelse liefdessymbolick van veel stılleven-motieven in Nederlandse 'Andachtsbilder' van Maria en het kind uit de periode I 450-1550

49 Verschillende auteurs hebben een onderscheid gemaakt tussen het 'realisme' of 'natu ralisme' waatmee boeren en strllevens op de voorgrond van Aertsens voorstellingen A1n uitgebeeld, en een 'romanistische' of 'calligrafische' stijl voor de religieure scenes op de achtergrond - 1c b v Btuyn 1965, 358, Kreddl 1972, 64 en 68, Buchan 1975, 98, en Moxey 1977A, 5759 Zoals men kan opmaken uit bovenstaande discussie over de weergave van boeren, hjkt het mij in elk geval weing nnvol dit onderscheid tc formuleren in termen van 'realisme' versus 'romanisme' - een crienis, dunkt me, van nationalistisch georicntecrde kunstgeschiedschrijving uit de eerstc holft van dese ecuw Het onderscheid is ook niet bepaald door cen tegenstelling tussen profane en religicuze thematick - cen observatie die Moxey reeds heefi gedaan Z/1n bewering dat dit verschil 'simply an aspect [1s] of Aertsen's artistic vocabulary' (bid, 59), houdt echter geen bevredigende verklaring in $M$ i gaat het om ecn verschil tussen een nadrukkclijke, 'stıllevenachtige' presentat1e, soals Raupp dit noemt, voor de vourgrond motieven, en cen vluchtiger schildering, (1n Bruyns woorden) ecn 'calligrafi sche' stijl, voor de achtergrondscencs, die gezien hun klcine afmetingen allecn in hun omtrekkcn duidelijk /rchtbaar moeten 71 n (en vanwegc dcrc eigenschap met een Italiaans aandoende lijnvoering $/ 1$ in geschilderd)

50. De motieven vormen ecn uttbreiding van een repertoire dat rceds in de landschappen van Herri met de Bles en de Brunsw1 kse Monogrammist dan te treffen als de markt waar van boeren - re Falkenburg 1988B

51 Munchen, Alte Pinakothek, Bayerische Staatsgem Samml, Inv nr I 3400 Buchan 1975, 228, schrifft dit werk op stilistısche gronden toe aan een navolgcr van $\Lambda e_{\perp} t s e n$ (welke dere gronden ajn is niet geheel duidelyk het werk /ou stilistisch in de jaren I $57^{\circ} 1575$ te dateren $711 \mathrm{n}$, maar te weining 'brcath' hebben om eigen handig te $/ 1 n$ ) In elk geval gaat het bij dit schilderij om een conceptie die veclvuldig in Joachim Beuckelaers voorstellingch van marktscenes met een Ficce homo aan te treffen is, maar dic tevens nauw aansluit bij Aertsens vroege schilderjen mct het/clfde thema, welke op hun bcurt nauw verbonden /1jn met Jan van Amstels tece bomo in het Mauritshuss ic Den Jlaag inv nr 960 Fen toeschrijuing aan Acrtsen elf blyft in 1 diarom tot de gerede mogel 1 kheden behoren

52 Opvallend is dat de komposities in des schilderijen precics verbeclden wat Albert1 expliciet vcroordeelt Wil een 'historia' aangenaam en 'ornata' rupt, moet re 'copla' en 


\section{'Alter Einoutus': Aertsens stillevenconceptie}

'varıetas' hebben - en dit is het geval, al is het net een 'copra' van lichamcn (corpora) maar van wat ook in Albcrt1's ogen zeker onbeduidend bijwetk 7ou $/ 1$ n, cn betreft dc 'varıetas' alleen de verschillende soorten produkten van het veld Albcrut tekent hier echter bij aan (en 1k citeer het over kompositie handelende boek Il van Alberti's $D e$ puttura naar de vertaling van $\mathrm{M}$ Baxandall, Gutto and the Orators Humamst obscivers of painting in Italy and the descovery of puctorial compositzon 1350 r450, Oxford $197 \mathrm{I}, \mathrm{I} 36)$ 'But I should wish this copia to be ornata with a degrec of varretar, and also gravis and moderata with degnatas and perecundia I certanly condemn those panters who, because they wish to secm copoos or because they wish nothing left empty, on that account pursue no compositio But indeed they scatter everything round in a confused and dissolutus way, on which account the bistoria scems not to enact but rather disorder its matter ( )' Utt dit oogpunt 71 1n Aertsens stilleven-voorstellingen 'dissolutus' en hebben 71 in het gcheel gcen 'compositio' - vgl het commentaar op dere pasıage van Baxandall, I36-139 Ik beschouw Albert1 overigens niet als cen dirckte bron voor $\Lambda$ ertsens inventics, maar wel als een mogelı $\mathrm{k}$ teferenticpunt, aange/ıen rijn geschriften ook in de $x 6$ de eeuw werden ge $/$ en als de verwoording van de hlassieke regels van de kunst Zie hicronder voor de suggestie dat Acrtsen mogelijh op/ettclijk de klassieke regels van de kunst heeft wllen schenden

53 Tegen de achtergrond van deze interpretatie krijgen de woorden van Iladranus Junius, in s1]n Batavia, Antwerpen 1588, 239-240, extra gewicht Juntus regt over Aertsens kunst 'Neque silentio praetercundus est Petius cognomento Longus, quem $\mathrm{Py}$ rcico Plinis comparatc uute, si non anteferre videor posse, qui ex proposito, vt apparet, humilia penicillo secutus, humiltatis summam adcptus est omnium udicio glotiam, ac propterea rbyparograpbur cognomine cum illo pa1ter insignitı, vel me atbitio, potest, vsqueadeo in operibus illius vbique rclucct gratia quacdam, exptesso elegantissime in rusticanıs puellis cotports filo habituque, obsonis, olcribus, mactatis pullis, nnatibus, asellıs, piscibusque aliss, culina11o denıque instrumento omn1, tta praeter consummatam voluptatem, infinita etiam varietate, tabulae ipsius oculos nunquam satiant que fit vt plur1s eae vaenant, quam multorum accuratac maximaeque' (Muylle 198687 (noot I), $16, \mathrm{n}$ 4, geeft als vettaling 'Ook aan Pietet, bijgenaamd 'dc Lange', mogen we niet strl/w1gend voorbijgaan Naar mijn mening han men hem terecht vergelijken met Pyreicus, die bij Plintus vermeld wordt, als men hem al niet de voot keur mag geven Welbewust, 7oals blykt (u1t /11n werk), legde bij /1ch toc op het schilde1en van getinge dingen, en heeft hi1, naai leders overtuiging, de hoogste roem bercikt in dere cenvoudige dingen Biggevolg kan hi\}, naat mijn mening althans, cvengoed als die andere, onderscheiden worden met de bj|naam 'ihyparographus' (schildet van gemene en getinge dingen), dermate weerglanst in $/$ ijn werken alom een bevalligheid, wanneet hij op de meest oogstrelende wijze de lichaamsvormen en de kledil van bocremeisjes wecrgeeft, levensmiddelen, groenten, geslachte kippen, conden, kabeljouw cn andere vissen, en tenslottc allerhande keukengeres Th op die mantet kunnen $/ 1$ ja schilde11jen, met uit/ondeing van het volkomen genot dat $/ 1$ bicden, zelfy doot hun eindelore var1etest, de ogen noost ver/adigen Daardoot worden $/ 1$ voor een hogete puls ver kocht dan rotgvuldig geschilderde en reer giote wetken van vele andetc meesters ') Afge ien van het felt dat Aertsens kunst in het tehen van de navolgng van de antiele 'rhyparographus' Pirakos wordt geplaatst, spreekt Junius explicict vat ncderige onde. werpen ('humilıa') die Aertsen opzettelijk ('cr proposito') verhoos te schilderen, en die hij 'elegantissime' heeft weten weer te geven, waardoor $7 j$ in werken 'gratia' berstten

54 Opus chronographocum () I6r1, 470 ('In dere tijd stond in aan/en Johannes 1 inout, ook een uitstekend schilder, dic, daat toe aangeret door het voor becld wan de [Lof de1] Zotherd van $/ 1 \mid \mathrm{n}$ stadsgenoot D Erasmus, op een wit paneel een voorstelling schilde1de van Christus grenageld aan het kius, waa1n mei de gedaanten an misvoinde monsen $\lrcorner a g$, verschillend van hleui en utecnlopend van /vormen|canon, godat kun stenaars de fouten van alle beroemde schilders daarın gewaat honden wotden en het schijnt relfs dat hij net alleen met hunstenaals mat ook met de kunst [/elt] de spot heeft gedreven Plete1 de Lange, de schildet, waardecrde dit schildenij o/cer, dat hi] 
my [d w z Van Opmecr] ^e dat de waarde crvan niet kon wordcn ustgedrukt in goud, mar [slechts] in ecn of ander aan/enlyjk ambt') Van Opmeer lict /11n Opus de periode 'a mundı exord1o' tot hot jaar i 569 bestrijken, waarna Lucas Besjerlink de periode tot het jaar I6I I beschreef- 1e I M Veldman, Maarten van Heenskerck and Dutch humansm in the sixteenth century, Amsterdam 1977, 98, n 9 Van Opmeer moet ecn goede bekende van Aertsen $/ 1$ n geweest, daat hij hem op ook diens sterfbed heeft be/ocht, coals hij vermeldt in /1n Historia Malyrum Batavicorum ( ), Coloniac r625, I54 (overigens vergelijkt ook Van Opmecr in dit geschtift Pieter Acrtsen met de antiche schilder Piraikos)

557 ic voor de populariteit en analyses van dit genre in de 16 de ceuw in het algemecn o a A Hauffen, 'Zur Litteratur der ironischen Inkomicn', Vurtolgabrscbrift fur Littcratur

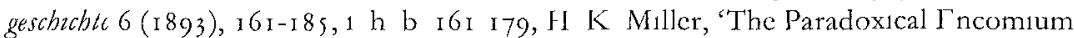
with spccial reference to 1ts vogue in $\Gamma$ ngland, I 600-i 800', Modern Pbilology 53 (1956), 145-178, A E Malloch, 'The technuques and function of the Renaissance Paradox', Sucdes an Pbilology 53 (1956), igr 203, R L Colie, Paradoxia cpidinuca I be Renassance Tradizon of Paradox, Princeton 1966, en M G M van der Poel, Dc Declamatio by de Humanisten Budrage tot de studte van de functus van de rhiorca in de renaissance, (diss Nijmegen) Nieuwkoop I987, 199-205 7ie voor analyscs van speciaal Frasmus' Lof der Zothead vanuit het perspectief van dce traditie ook W Kasser, Prazsers of Folly Lrasmus, Rabilas, Sbakespiare, Cambridgc (Mass) i 963, en D G Watson, 'Erasmus' Prazse of Folly and the spirit of Carnival', Renassance Quarlerly 32 (1979), 333-353

56 Zie voor het paradoxal encomium in de klassieke literatuur ook $T$ C Burgess, Itpideatic Latcrature (University of Chicago Studics in Classical Philology) III, i902, 89-261, en A S Pease, 'Things without IIonor', Classzcal Phlology 2 I ( 9 926), 27-42

57 7ie vooral Miller 1956 (noot 55), 145 fi Miller egt dat cr voor het overige geen precicse regels voor de kompositse van de paradoxale lofrcde sjn ontwikkeld

58 \%o ook Crasmus die in $/ 1 \mathrm{jn}$ voorrede o a als $/ j \mathrm{n}$ anticke voorbeelden nocmt Lucianus (auteur van de Laus muscae, ecn lofrede op de vlieg, en de Lragopodagra, cen tragedie over de jucht), de Balrachomyomachta, een heldendicht op cen kikvorsenge vecht, in Crasmus' tijd staande op de naam van Homerus, (pseudo) Vergllus' Culex (de Mug) en Morclum (de Stamppot), (pseudo-)Ovidius' Nux (de Notcboom), en Syncsius' Calman encomum (de L.of der Kaalheid) Je Miller 1956 (noot 55), r54, en Eramus Lof der Zoibud, vert door $A$ J Iliensch, Utrccht-Antwerpen 1972, 8 Гcn indicatic voor de verbresdherd van het genre in de ibde ceuw vormen enkele grote bundelingen van rulke encomia uit het begin van de i $7 \mathrm{dc}$ ceuw, waaronder het $A m$ pbubbeatrum Sapunizac Socralcac boc cst Lncoma et Commontaria Autorum qua veterum qua recntionum prope omnum (), (I Ianover 1619) van Caspar Dornavius, waarin meer ran soo Lat1jnsc paradoxale encomia van antekc en moderne auteurs staan opgesrmo AC I Iauffen 1893 (noot 55), I64, cn Miller 1956 (noot 55), 152

59 Z1e Malloch 1956 (noot 55), I92 en 195 196, Colse ig66 (noot 55), 134 I35, Van der Poel 1987 (noot 55), $20020 \mathrm{I}$, en vgl Sistcr M Geraldine, 'I rasmus and the tradituon of paradox', Studes in Pbilology 6I (I 964), $4 \mathrm{If}$ en 48 I rasmus hecft dic mogelijkhcid dat de leser de hem toebedeclde rol nict speclt, onderkend cn relfs uitgelegd an een contemporaine foutieve verstaander, de thcoloog Martin Dorp / Watson 1979 (noot 55), 340-34 I In de Lof der Lotberd is zelfs sprake van ecn veclgelaagde en dubbele paradox het maakt duidel ljk dat allcen do w w je tot cen in/cht in /1jn cigcn dwaasherd komt en de 'dwaashesd in Christus', waarop de oratie van Vrouwe 'Dwaasheid' in dit geschrift uitloopt, al trachten na tc streven - se voor dere 'dwaasheid in Christus' als het crucialc thema van de Lof der Lolbud ook Sister G, Thompson, Under Prelcxt of Pratse Saltric Mode in Lrasmus' Futzon, Toronto-Buffalo 1973, en $M \wedge$ Screcch, Lestasy and 'I he Pratse of Folly', Londen 1980

(0) Zie Cols 1966 (noot 55), 273299

(1) Onder verwij/ng naar Gombrich 1978 (noot 8) dudd Colk het budrog der antulgen, dat besloten ligt in de inneprikkelende voorstelling van frut c d op cen 'hard cold pancl', als cen verwil/ng naar dc 'vanitas'-gedachte, waarbil ook cen moraliserende kritiek op de neiging van de beschouwer om 'toe te tasten' in het spel is tbud, 274 
'Alter Eznoutus': Aertsens stillevenconceptie

62 Ibsd, 276, vgl 64 en 70.

63 Raupp 1986, 217-2 8 .

64 B.v. in de Terugkeer van de processze, Brussel, Konınklijke Musea voor Schone Kunsten, Inv nr. 7524 .

65 Zie Irmscher 1986.

66 De suggestie van het aanzitten door de beschouwer met de beeld-protagonsten aan éćn tafel is een motief dat ook uit het traditionele 'Andachtsbild' afkomstig kan ziln le b v Jan Mostaert, De H. I'amize by de maaltyd, Keulen, Wallraf-Richartz-Museum (se voor een afb. de tent.cat. Stilleben in Europa, Munster (Westfalisches Landesmuseum) / Baden-Baden (Staatliche Kunsthalle) i980, 266).

67 Dit aanprijen kan zijn ingegeven door de lofpriyzing die inherent is in de ter discussie staande stilfiguur - zie noot 68 -, maar kan ook ingegeven zijn door aanprijzende gebaren in het orthodoxe 'Andachtsbild' - vgl. H. Belting, Das Bild und sem Publikum im Mittelalter. Horm und Funktion fruber Buldtafeln der Passion, Berlijn I98 I, I 10.

68 Zie voor de 1 de i6de eeuw gangbare koppeling van 'voluptas oculorum' en 'voluptas carnıs' Irmscher 1986. Irmschers herleiding van het motıef van de marktluı in Aertsens en Beuckelacrs schildetijen tot Ciccro's De officuzs en de daaruit voortvloeiende 1 konologische duiding van deze schilderijen is voor het overige aantoonbaar onjust - zue Falkenburg I988B. Bocren en marktlu1 bchoren ook tot het motievenrcpertolrc van het litcraire paradoxaal encomium: (pseudo-)Vergiluus' Moretum - een lofprijzing van een boerenmaaltijd - is reeds gememoreerd (Lie noot ; 8), en Rabelais makt urtvoerig gebrulk van de figuur van de marktkoopman om de lezer allerhande 'lage' saken (mot scatologische en sexuele connotaties!) aan te prijzen - zie M. Bakhtin, Rabelars and His World, trans. H. Iswolsky, Cambridge (Mass.)/Londen 1968, i60-189, en D N. Losse, Rbetoric at Play. Rabelats and Sattrical Eulogy, Bern-Frankfurt a/M / Las Vegas 1980 , 1.h.b 33-4 $\mathrm{x}$ en 50. Overigens is de vergelijking tussen de lofpri1zingen van de orator en de aanprijzingen van u1tgestalde waar door de marktkoopman, waar Rabelais mec speelt, al te vinden bij Quintilianus - z1e Qunttlanus. The insiututio oratora of Quntilan, with an Lnglash translation by $H$. E Butler, Londen/New York 1920, bk. VIII, 111, II-I 2 -, dic in dit verband het woord 'institor' (venter) gebrukt, vgl. D Erasmus, Erasm Roterodam moride encomum I Stultuad laus, Bazel (J. Fiobenius) i5 I5, B2r, waar Erasmus, resp. Vrouwe Dwaashe1d, de tochoorders aanraadt 'goed naar mij [te] lusteren, niet met dat halve oor, dat gij aan boetpredikers plecgt te schenken, maar met de aandacht waarmee g1) marktschreeuwers [circulator1bus], puassen en hansworsten aanhoort (. )' - gecit. naar de vertaling van A. Dirkswager Can en A. C. Niclson, Stultatude Laus. De Lof der Zotbezd, Amsterdam 1949, 16 en 17 Aertsen kan 71 n inspiratie voor het motief van het aanprijen van etenswaren door marktlly, en voor de toeberetding van cen boerse maaltıjd (in de Pannekoekeneters - wat men zou kunnen omdopen in zolets als de 'Lof der pannekoekeneters') dus ook uit contemporaine litera1re voorbeelden van het paradoxaal encomium geput hebben In cen op stapel staande studie over de marktscènes en keukenstukken van Aertsen en Beuclelacr $/$ al $\mathrm{k}$ nader ingaan op de functie van de $z$ voorstellingen tegen de achtergrond van dese stılffiguur, alsook op de relatie van deze schilderijen met de ikonografic van het I 6de-eeuwsc landschap en de thematiek van de twee levenswegen, die verweven is met het thema van het 1nzicht in de eigen zondigheid dat hier aan de orde 15.

69 'Tot cen dergelijke uitleg van de bewegingen der armen van de prostitués komt Wallen 1983,63 , wel bij z1jn andyse van Van Hemessens Bordeelscìne (1 943) in Hartford, niet cchter bij zijn bespreking van het stuk in Brussel - a1e verder Wallen, passim, voor de overname van moticven uit de Italiaanse renaissance in het werk van Van Hemessen.

70 Raupp 1986 benadrukt steeds het heterogene karakter van het door hem gepostuleerde 'genus satyricum' Zie Thompson 1973 (noot 59), 5 I-85, voor de verwevenheld van de st1]figuur van het patadoxal cncomium met de parodie, de ironie en de satire in Erasmus' Lof der Zotbid; en vgl D.P. Pers, Suyp-stad of Dronckaerts Leven, (eds. J. Verlaan en H. Grootes), Culemborg 1 978, 64ff., voor een uttecnzetting van het feit dat het satırc-begrup in de litera re praktijk van de r 6 de en 17 de eeuw zo ruim was dat het ook het paradoxal encomium kon omvatten 


\section{Summary}

\section{'Alter Einoutus': The Nature and Origin of Pieter Aertsen's Still- Life Conception}

\section{R. L. Falkenburg}

In this article 1s offered the hypothesis that form and content in Pieter Aertsen's still lifes just as in a number of his peasant scenes - are in a certain sense each other's opposites and that this antithesis is based on the rhetorical literary genre of the 'paradoxical or ironic encomium' First of all an explanation is given of how the Modus der Buldsprache of Aertsen's still lifes can be traced back to a certain type of devotional pantung of the late Middle Ages From the fact that the form of presentation traditionally used for sacred figures and their ambiance is now applied to the painting of peasants, market-stall holders and kitchenmaids and their surroundings it is deduced that what we have here is a 'high' form of presentation for a 'low' content It is then pointed out that such a discrepancy has also been detected by varıous authors in Aertsen's peasant scenes, which hark back to the formal canon of the Italian Renarssance From the carefully staged compositional chaos and absurdity in a number of vegetable-stall scenes there likewrse emerges a tendency towards a metaphorical use of 'high' compositional principles for 'low' ends, as well as a sattsical intention on the part of the painter This intention and the discrepancy between form and content are traced back to the rhetorical literary genre of the "paradoxical encomium', which Aertsen may have known va Erasmus' In Pralse of Holly On the basis of this genre the conception behind his still life compositions is distilled as a painterly culogy of unworthy subjects The moral lesson for the spectator, which has already been noted in Aertsen's paintings by vartous authors, is inherent in the sixteenth-century literary 'paradoxical encomium' and seems equally to derive from it W/th this thematization of the relation between form and content and with their moralizing intention, Aertsen's still-life compositions enturely fit into the genus satyrum, as recently defined by Raupp 